*ak RMIS View/Frint Document Cover Sheet tow

This document was retrieved from the Documentation and Records Manaqement (DRM) ISEARCH System. It is intended for Information only and may not be the most recent or updated version. Contact a Document Service Center (see Hanford Info for locations) if you need additional retrieval information.

Accession \#: D196002441

Document \#: SD-WM-PD-046

Title/Desc:

TWRS INACTIVE MISC UNDERGROUND STORAGE TANKS PROGRAM PLAN

Pages: 74 







\title{
Tank Waste Remediation System Inactive, Miscellaneous Underground Storage Tanks Program Plan
}

\author{
R. D. Gustavson \\ Westinghouse Hanford Company, Richland, WA 99352 \\ U.S. Department of Energy Contract DE-AC06-87RL10930 \\ EDT/ECN: 613418 UC: \\ Org Code: 77530 Charge Code: N1436 \\ B\&R Code: \\ Total Pages: 71
}

Key Words: TWRS, Tank Waste Remediation System, IMUST, Inactive Miscellaneous Underground Storage Tanks, Program Management Plan, CCS, Controlled Clean and Stable.

Abstract: The Program Management Plan (PMP) describes the approach that will be used to manage the Tank Waste Remediation System (TWRS) Inactive Misce 11 aneous Underground Storage Tank (IMUST) Program. The plan describes management, technical, and administrative control systems that will be used to plan and control the IMUSTs Program performance. The program has two primary functions. The first is to evaluate current technical data to determine the IMUSTs status for inclusion in the Single Shell Tank Farm Controlled Clean and Stable (CCS) Program. The second is to identify and implement surveillance, characterization, stabilization, and modifications to support CCS prior to final closure.

TRADEMARK DISCLAIMER. Reference herein to any specific comercial product, process, or service by trade name, tradenark, manufacturer, or otherwise, does not necessarily constitute or imply its endorsement, recommendation, or favoring by the United States Goverment or any agency thereof or its contractors or subcontractors.

Printed in the United States of America. To obtain copies of this document, contact: WHC/BCS Document Control Services, P.0. Box 1970, Mailstop H6-08, Fax (509) 376-4989.
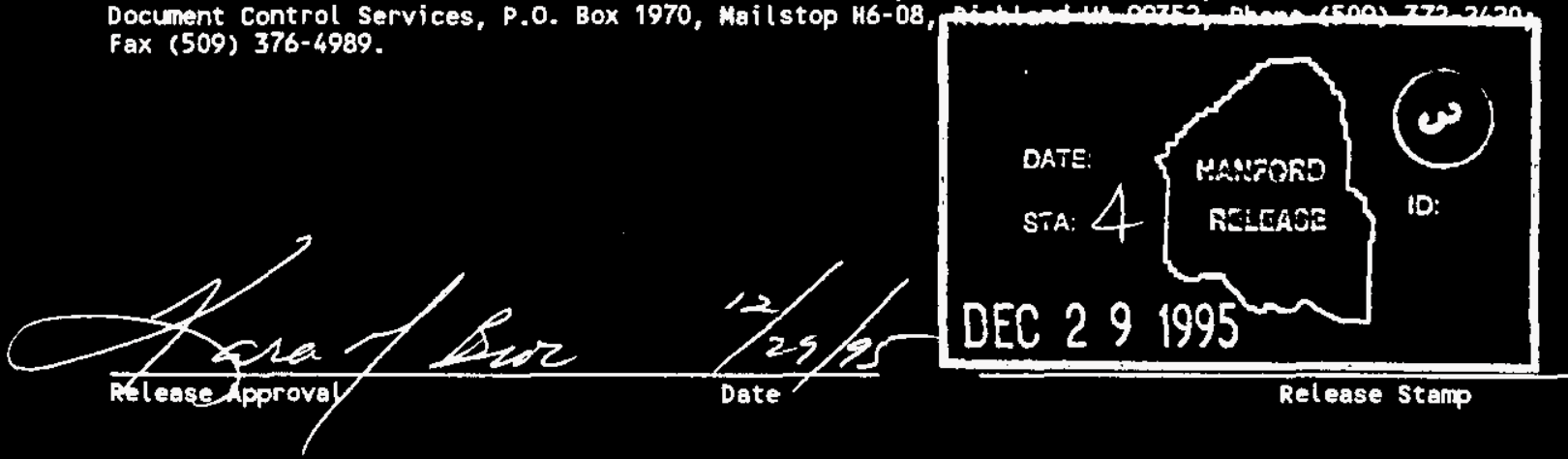

Approved for Public Release 


\title{
TANK WASTE REMEDIATION SYSTEM
}

\section{INACTIVE MISCELLANEOUS UNDERGROUND STORAGE TANKS PROGRAM PLAN}

\author{
Prepared by: \\ Parsons Engineering Science, Inc. \\ Richland, Washington
}

Systems Engineering Support

Task Number 379954-018 


\section{TABLE OF CONTENTS}

1.0 INTRODUCTION . . . .

1.1 Program Background . . . . . . . . . . . . $1-5$

1.2 Program Vision, Mission, and Strategies . . . . . . . . $1-8$

1.3 Program Participant Roles and Responsibilities . . . . . 1-8

1.4 Assumptions and Conditions . . . . . . . . . . 1-10

2.0 PLANNED PROGRAM ACCOMPLISHMENTS . . . . . . . . . . $2-1$

2.1 Requirements Application . . . . . . . . . . . . 2 .

2.2 Objectives . . . . . . . . . . . . . . 24

2.2.1 Systems Engineering ........ . . . . . 2-4

2.2.2 Program Statement of Work ... . . . . . . . 2-5

2.2.3 Program Work Breakdown Structure . . . . . . . . . 2-6

2.3 Schedule Objectives . . . . . . . . . . . . 2-6

2.4 Cost Objectives . . . . . . . . . . . . . . .

2.5 Communications objectives . . . . . . . . . $2-8$

2.6 Integration Objectives . . . . . . . . . . . . . 2

3.0 MANAGEMENT SYSTEMS AND CONTROLS ............ . . 3-1

3.1 Organization . . . . . . . . . . .

3.1.1 Tank Waste Remediation System Environmentai Engineering and Inactive Miscellaneous Underground Storage Tank Program Relationships

3.1.2 Inactive Miscellaneous Underground Storage Tank Program Office

$3-3$

3.1.3 Responsibilities, Authorities, and Accountabilities $3-4$

3.2 Planning and Budgeting ......... 3-4

3.2.1 Systems Engineering . . . . . . . . 3-4

3.2.2 Multi-Year Program Planning . . . . . . . . . . . . . . 3-4

3.3 Work Authorization and Control . . . . . . . 3-5

3.4 Scheduling and Budgeting . . . . . . . . . . . 3-5

3.5 Program/Project Execution . . . . . . . . 3-5

3.6 Performance Measurement and Reporting . . . . . . . . . . 3- 3-6

3.7 Program/Project Closeout . . . . . . . . . . . . 3-6

3.8 Records and Information Management . . . . . . . 3-6

3.9 Communication Management . . . . . . . . . . 3-6

3.10 Integration Management . . . . . . . . . . . . . . $3-7$

4.0 BASELINE SYSTEMS AND CONTROLS . . . . . . . . . . . . . 4-1

4.1 Technical Baseline Management . . . . . . . . . . . . . . . . 4 4-1

4.2 Configuration Management . . . . . . . . . . . . . . $4-2$

4.3 Interface Management . . . . . . . . . . . . . . . . . . . . 4-3

4.4 Quality Assurance Management . . . . . . . . . . . . . . . 4-4

4.5 Technical Procedures and Plans . . . . . . . . . . . . . . 4-4

4.6 Technical Data Management . . . . . . . . . . . . . 4-5

4.7 Technical Peer Review Management . . . . . . . . . . . . . . $4-6$

5.0 ADMINISTRATIVE SYSTEMS AND CONTROLS . . . . . . . . . 5-1

5.1 Security

5.2 Environmentaj Health and Safety . . . . . . $5-1$

5.3 Personnel . . . . . . . . . . . . . . .

5.4 Contracts . . . . . . . . . . . . .

5.5 Database Management . . . . . . . . . . . . . . . . 5-1

5.6 Property Management . . . . . . . . . . . . . . . . . . . . . 5-2 


\section{TABLE OF CONTENTS}

(Cont inued)

5.7 Subcontracts Control .............. . 5-2

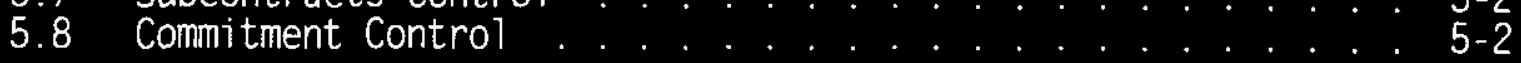

6.0 REFERENCES ..................... . . . . . . . . . .

\section{APPENDICES}

A Tank Locations for Inactive Miscellaneous Underground Storage Tanks . . . . . . . A-1

B Program Strategy and Historicai Basis for Inactive Misceilaneous

C Underground Storage Tanks Tanks

\section{LIST OF FIGURES}

1-1 Inactive MiscelTaneous Underground Storage Tanks Management Strategy 1-2

1-2 Summary Funding Profile for Inactive Miscellaneous Underground

Storage Tanks Program . . . . . . 1-2

1-3 Summary Schedule for Inactive Miscellaneous Underground Storage Tanks Program . . . . . . . . . . . . . .

1-4 Summary Work Breakdown Structure for Inactive Misceilaneous Underground Storage Tanks Program . . . . . . . . . . . . 1-4

1-5 Summary Organization Chart for Inactive Misceilaneous Underground Storage Tanks Program . . . . . . . . . . . . . . 1-4

2-1 Document Hierarchy . . . . . . . . . . . . . . . . . . . . . . . 2-3

2-2 Schedule Hierarchy . . . . . . . . . . . . . . . . . . . . . . . 2-7

2-3 Key Interface Organizations . . . . . . . . .

3-1 Systems, Controls, and Reporting Requiremetns for the Inactive Misceilaneous Underground Storage Tank Program Functional Requirements . . . 3-2

3-2 Tank Waste Remediation System Environmental Engineering Summary Organization Chart . . . . . . . . . . . . . 3-3

4-1 Planning and Baseline Development. 


\section{LIST OF TABLES}

1-1 Tank Waste Remediation System-Owned Inactive Miscellaneous Underground Storage Tanks . . . . . . . . . . . . . . 1-5

1-2 Inactive Miscelianeous Underground Storage Tanks Not Owned by Tank Waste Remediation System . . . . . . . . . . . . 1-6

1-3 Summary of Completed Milestones for Inactive Miscelianeous Underground Storage Tanks Program . . . . . . . . . . . . . . . 1-7

1-4 Summary of Near-Term Milestones for Inactive Miscellaneous Underground Storage Tanks Program . . . . . . . . . . . . . . . 1-8

1-5 Responsibility and Accountability Matrix for Inactive Misceilaneous Underground Storage Tanks . . . . . . . . . . . . . . 1-9

1-6 Tank Farm Transition Projects Integration Program Assumptions and Constraints . . . . . . . . . . . . . . . .

2-1 Inactive Misceltaneous Underground Storage Tanks Major Lifetime Accomplishments . . . . . . . . . . . . . . . . 2-1

2-2 Summary of Requirements objectives . . . . . . 2-2

2-3 Summary of Key Schedule Drivers . . . . . . 2-4

2-4 Key Interface Organizations Assigned Functions . . . . . . . . . . . 2-10

4-1 Tank Waste Remediation System Technical Procedures . . . . . . . . . 4-5 


\section{LIST OF ACRONYMS}




WHC-SD-WM-PD-046, Rev 0

\subsection{INTRODUCTION}

This Program Management Plan (PMP) describes the approach that will be used to manage the Tank Waste Remediation System (TWRS) Inactive Miscellaneous Underground Storage Tank (IMUST) Program. The plan describes management. technical, and administrative control systems that will be used to plan and control the IMUST Program. The plan also describes relationships between key program participants--Westinghouse Hanford Company (WHC) and the U.S. Department of Energy (DOE), Richland Operations Office (RL) --and interfaces between TWRS program elements such as operations, maintenance, systems engineering, safety, and upgrade projects.

The TWRS IMUST Program has two primary functions:

1. Evaluate current technical data and information to determine the IMUSTs status for inclusion in the Single-Shell Tank Farm Controlled. Clean, and Stable (CCS) Program; and

2. Identify and implement surveillance, characterization. stabilization, and modifications to support CCS prior to final closure.

After reaching CCS, tank farms storage elements will be managed by a skeleton crew unt $i 1$ the group managing retrieval and closure is prepared to accept the tanks. This goal is tentatively scheduled to be met in the year 2005 . The ultimate goal of the IMUST program is to meet the CCS requirements, after which. the IMUST program will be complete. Long-term tank management is the responsibility of TWRS Transition Projects Operations groups at the Hanford Site East and West areas.

The TWRS IMUST Program will be managed by implementing quality management principles. Sufficient rigor will be exercised to ensure technical and administrative credibility of all functions: and defensibility of all assigned program and project data acquisition, analyses, evaluations, decisions, and technical work. Continuous Quality Improvement processes will be implemented to ensure continuous improvement of functions and activities; and systems engineering (SE) processes will be used to ensure appropriate development and management of technical baselines.

The IMUST Program wi11 be required to comply with applicable Federal and Washington State regulations, including the Hanford Federal Facility Agreement and Consent Order [or Tri-Party Agreement (TPA)]. This compliance incorporates solicitation from public interest groups, the Hanford Advisory Board. Defense Nuclear Facility Safety Board (DNFSB), Native American Tribes, and other stakeholders. The program also will be constrained by the DOE and Hanford Site budget funding allocations and priorities, and functional interrelationships between TWRS, Environmental Restoration, and other programs.

Figure 1-1 depicts a high-level program overview. Figure 1-2 is a Summary Funding Profile, Figure 1-3 is a Summary Schedule, Figure 1-4 is a Summary Work Breakdown Structure, and Figure $1-5$ is the Summary Organization Chart. Funding estimates assume limited vapor sampling and no core sampling. 
Figure 1-1. Inactive Miscellaneous Underground Storage Tanks Management Strategy.

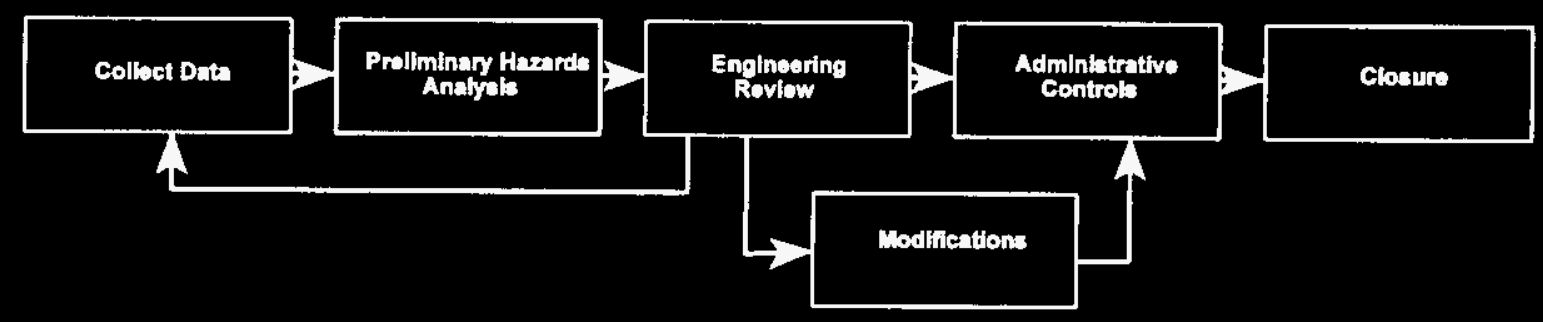

Figure 1-2. Summary Funding Profile for Inactive Miscellaneous Underground Storage Tanks Program.

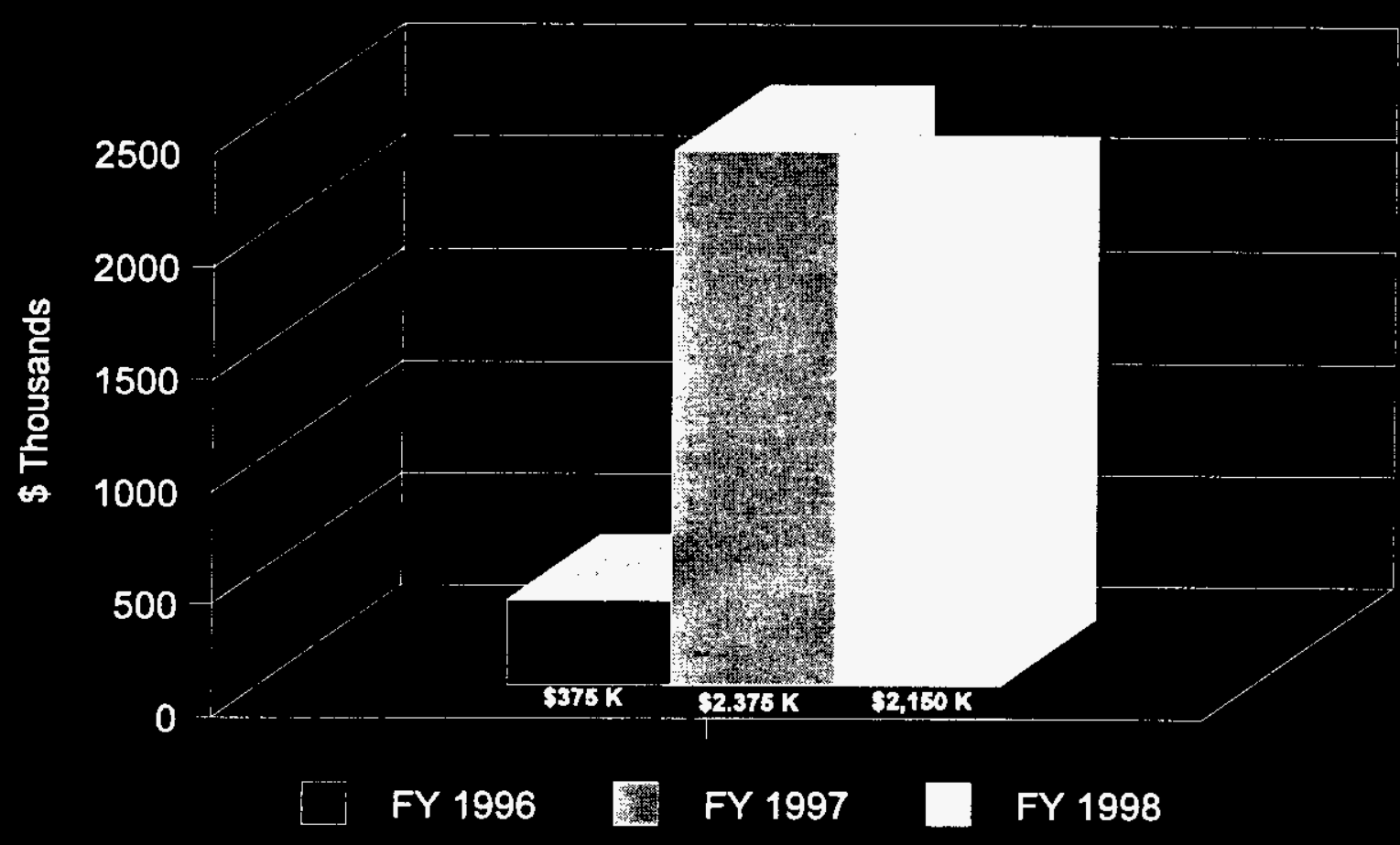


Figure 1-3. Summary Schedule for Inactive Miscellaneous Underground Storage Tanks Program.

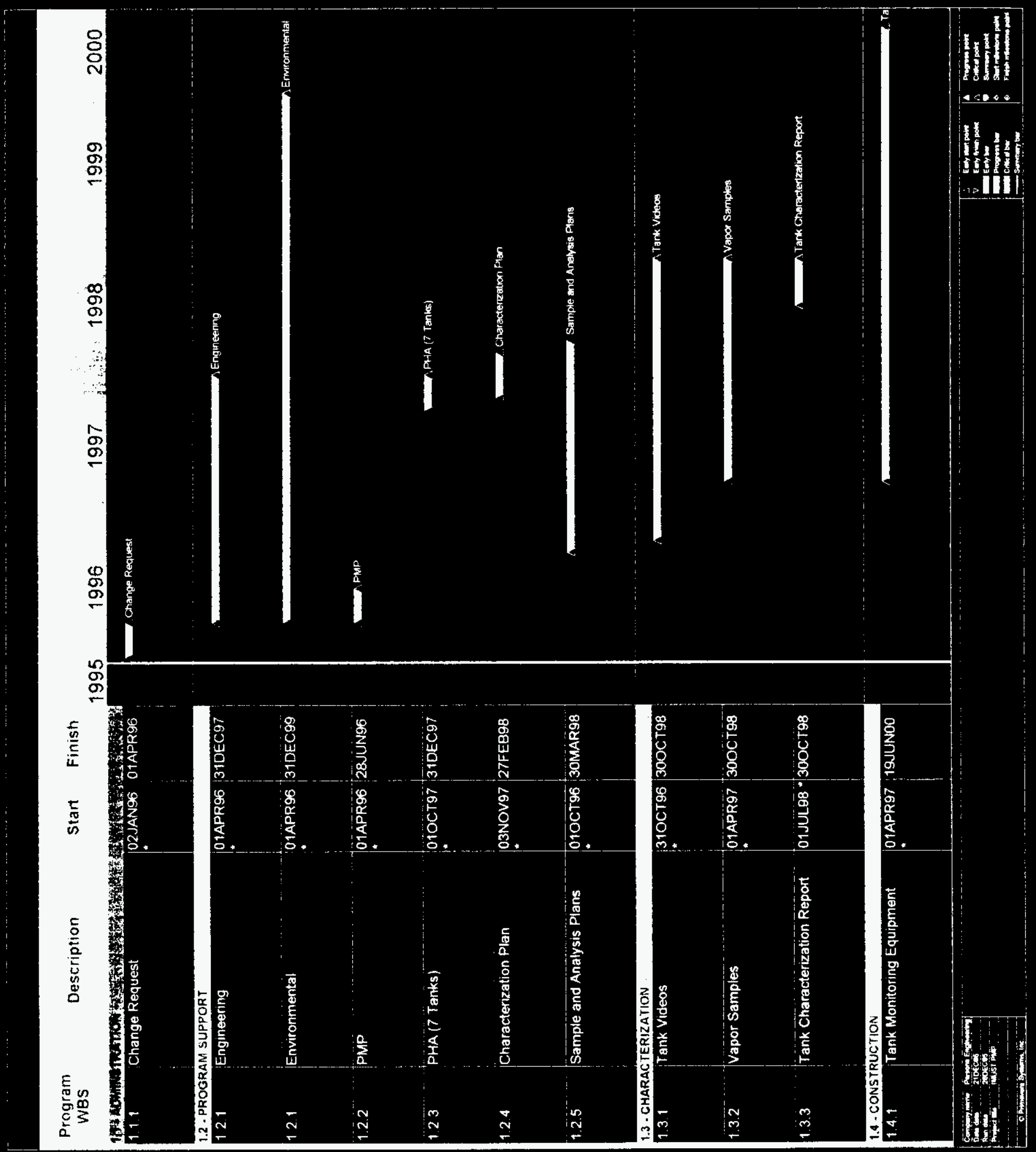


Figure 1-4. Summary Work Breakdown Structure for Inactive Miscellaneous Underground Storage Tanks Program.



Figure 1-5. Summary Organization Chart for Inactive Miscellaneous Underground Storage Tanks Program.






\subsection{Program Background}

The TWRS IMUST Program was initiated after completion of an engineering study of 50 IMUSTs in 1994. The 50 tanks evaluated included 29 tanks for which TWRS is responsible. A Preliminary Hazards Analysis (PHA) was completed in 1995 for the same 50 tanks. This PHA concluded that "the IMUST potential safety issues ... are relatively small when compared to other facilities within TWRS." The PHA also concluded that "the IMUST potential accident consequences are bounded by the Accelerated Safety Analysis (for the Single-Shell Tanks)." These conclusions were based on limited data, which necessitated assumptions regarding the IMUST contents and internal tank reaction mechanisms.

This PMP proposes some limited characterization and tank inspections. In addition to the 50 IMUSTs evaluated initially, 13 additional tanks were identified. The TWRS is responsible for seven of these additional tanks. A safety evaluation or a revision to the PHA will be required for these seven tanks. Table 1-1 provides a list of the 36 identified IMUSTs for which TWRS has assumed responsibility, and Table 1-2 provides a list of the 27 tanks not owned by TWRS. The TWRS IMUST ownership is based on the TWRS Management Plan for the Hanford Site 200 Area IMUSTs, as documented in a letter from WHC to RL (Lee 1995). Further discussions between DOE-RL and TWRS Environmental Restoration personnel may result in changes to the present ownership of the 63 Hanford Site IMUSTs. Should additional tanks be identified or transferred to TWRS, the PMP wi11 be reviewed and any necessary changes wi11 be incorporated.

Table 1-1. Tank Waste Remediation System-Owned Inactive Miscellaneous Underground Storage Tanks.

\begin{tabular}{|c|c|c|c|c|}
\hline Tank & Tank & Tank & Tank & Tank \\
\hline $241-A-302 B$ & $244-B X R-002$ & $241-S-302 A$ & $241-T X-302 A$ & $216-T Y-201$ \\
\hline $241-A X-151^{*}$ & $244-B X R-003$ & $241-S-302 B$ & $241-T X-302 B$ & $241-T Y-302 A$ \\
\hline $\begin{array}{c}241-B-301 B \\
\text { (01d \# 241-B-301) }\end{array}$ & $244-B X R-011$ & $241-S X-302$ & $\begin{array}{c}241-T X-302 B(R) \\
(01 d \# 241-T X-302 B R)\end{array}$ & $241-T Y-302 B$ \\
\hline $241-B-302 B$ & $\begin{array}{c}216-B Y-201 * \\
(01 d \# 216-B Y)\end{array}$ & $243 S-T K-1^{*}$ & $\begin{array}{c}241-T X-302 X \\
(01 d \# 241-T X-302 X B)\end{array}$ & $231-W-151-001$ \\
\hline $241-B X-302 A$ & $\begin{array}{c}241-C-301 C \\
(01 d \# 241-C-301)\end{array}$ & $242-T-135^{*}$ & $244-T X R-001$ & $231-W-151-002$ \\
\hline $241-B X-302 B$ & $\begin{array}{c}241-E R-311 A^{*} \\
(01 d \# 241-E R-311)\end{array}$ & $\begin{array}{c}241-T-301 \\
(01 d \# 241-T-301 B)\end{array}$ & $244-T X R-002$ & $270-W$ \\
\hline $241-B X-302 C$ & $240-S-302$ & $242-T A-R 1^{*}$ & $244-T X R-003$ & $241-Z-8$ \\
\hline $244-B X R-001$ & *Identified and added to the TWRS-Owned IMUST 1ist in 1995. \\
\hline
\end{tabular}


Table 1-2. Inactive Miscellaneous Underground Storage Tanks Not Owned by Tank Waste Remediation System.

\begin{tabular}{|c|c|c|c|c|}
\hline Tank & Tank & Tank & Tank & Tank \\
\hline $241-B-361$ & $\begin{array}{l}276-S-141^{\star} \\
(01 d \# 276-S-306 A)\end{array}$ & 244-UR-001 & $\begin{array}{c}\text { 244-WR-001 } \\
(01 d \# 241-W R-001)\end{array}$ & $\begin{array}{l}\text { 244-WR-006 } \\
(01 d \# 241-W R-006)\end{array}$ \\
\hline $216-B C-201^{*}$ & $\begin{array}{c}276-S-142^{\star} \\
\text { (old } \# 276-S-306 B)\end{array}$ & 244-UR-002 & $\begin{array}{c}\text { 244-WR-002 } \\
\text { (01d \# 241-WR-002) }\end{array}$ & $\begin{array}{c}\text { 244-WR-007 } \\
\text { (01d \# 241-WR-007) }\end{array}$ \\
\hline $241-C X-70$ & 292 T-TK-1* & 244-UR-003 & $\begin{array}{c}\text { 244-WR-003 } \\
\text { (01d \# 241-WR-003) }\end{array}$ & $\begin{array}{c}244-W R-008 \\
\text { (01d \# 241-WR-008) }\end{array}$ \\
\hline $241-C X-71$ & $292 T-T K-2 *$ & 244-UR-004 & $\begin{array}{c}\text { 244-WR-004 } \\
\text { (01d \# 241-WR-004) }\end{array}$ & $\begin{array}{c}\text { 244-WR-009 } \\
\text { (01d \# 241-WR-009) }\end{array}$ \\
\hline $241-c x-72$ & $241-T-361$ & 213-W-TK-1* & $\begin{array}{c}\text { 244-WR-005 } \\
\text { (01d \# 241-WR-005) }\end{array}$ & $241-z-361$ \\
\hline $270-E-1$ & $241-U-361$ & \multicolumn{3}{|c|}{$\begin{array}{c}\text { *Ident ified and added to the Non-TWRS-Owned IMUST list in } \\
1995 .\end{array}$} \\
\hline
\end{tabular}

Appendix A includes maps identifying the tanks and their locations and Appendix B includes an overview of the Program Strategy and Historical Bas is of Inactive Miscellaneous Underground Storage Tanks.

The 36 IMUSTs for which TWRS is responsible will be reevaluated to determine if they meet the endpoint criteria for transition of the Single Shell Tank Farms to the Controlled. Clean, and Stable (CCS) condition. To complete the transition to CCS. Some of the above noted characterization, tank inspection. and safety evaluation activities may have to be completed. If any of these activities identify a significant safety issue or risk factor, tank pumping. monitoring, or other mitigating measures may also be required. Once CCS has been achieved, the single-shel1 tanks (SSTs) and associated IMUSTs are ready for transfer to the Retrieval Project for waste retrieval, and Closure. Final closure of the IMUSTs is planned to occur with final closure of each of the operating units with which they are associated. Retrieval and closure of other TWRS-Owned IMUSTs outside of the SST Farms are planned to be performed with the associated Operable Unit.

Decisions regarding the majority of IMUST retrieval and closure activities wi1l be made within the context of SST retrieva1/closure plans. Any modifications to the IMUSTs will be completed on or before 2005, in concert with the Project $W-314$ capital upgrade project, which is planned to be completed in the year 2005. There are no specific Tri-Party Agreement (TPA) milestones for IMUSTS.

The PHA and an associated safety evaluation for the initial 50 IMUSTs were reviewed by the Tank Farm Transition Projects (TFTP) Plant Review Committee (PRC). The PRC concluded that the IMUSTs do not pose an Unreviewed Safety Question (USQ). After the USQ determination was completed, a new manager and staff were assigned to the IMUST Program. This new organization is within the Environmenta 7 Cleanup and Compliance Project, reporting to the TFTP. The Environmental Engineering organization has developed this Program Management Plan to implement systems engineering and quality management processes to manage the TWRS IMUSTs through the transition to CCS and final Closure. 
The primary objectives for the TWRS IMUST Program are as follows:

1. Prepare defensible engineering IMUST evaluations relative to CCS criteria, based on available engineering data and information; and

2. Identify, integrate, and manage IMUST characterization. inspection, upgrades, pumping, and safety evaluation activities required for long-term tank management until final closure.

Some major milestones achieved toward addressing these challenges are provided in Table 1-3 and near-term mi lestones to be met in addressing these challenges are provided in Table 1-4.

- Table 1-3. Summary of Completed Milestones for Inactive Miscellaneous Underground Storage Tanks Program.

\begin{tabular}{|c|l|c|}
\hline Number & \multicolumn{1}{|c|}{ Milestone Definition } & Date Completed \\
\hline \hline 1 & Guideline for Declaring Auxillary Tanks Interim Stabilized & 1984 \\
\hline 2 & $\begin{array}{l}\text { Stabilization and Isolation of Inactive Miscellaneous Underground } \\
\text { Storage Tanks (IMUSTS) }\end{array}$ & 1985 \\
\hline 3 & $\begin{array}{l}\text { Engineering Study of 50 Miscellaneous Inactive Underground Radioactive } \\
\text { Waste Tanks Located at Hanford Site, Washington }\end{array}$ & 1994 \\
\hline 4 & Preliminary Hazard Analysis for Initial 50 Tanks & July 1995 \\
\hline 5 & Safety Issue Resolution Strategy Plan for IMUSTs & September 1995 \\
\hline 6 & $\begin{array}{l}\text { IMUST Program transferred from Tank Waste Remediation System (TWRS) } \\
\text { Safety Program to TWRS Transition Projects. }\end{array}$ & October 1995 \\
\hline
\end{tabular}

\subsection{Progran Vision, Mission, and Strategies}

The IMUST Program Vision is as follows:

Establish and manage a program recognized for excellence in effective planning, oversight, and integration for continued safe management of the IMUST tanks unti1 final closure.

The IMUST Program Mission is as follows:

Define and manage the TWRS IMUST Program, and integrate all planned and ongoing engineering, characterization, and modification activities associated with the IMUSTs to ensure that they support the overa11 TWRS mission.

The IMUST Program Strategies are as follows:

1. Establish technical and managerial credibility through development, implementation, and closeout of well-defined plans and subtasks;

2. Use project management and systems engineering policies and processes in developing and managing technical baselines, decision making, and project control: 
3. Identify, define, integrate, and track technical work scopes, budgets, and schedules; and

4. Identify, define, and integrate technical and logistical interfaces within and between other associated projects and activities.

Table 1-4. Summary of Near-Term Milestones for Inactive Miscellaneous Underground Storage Tanks Program.

\begin{tabular}{|c|l|c|}
\hline Number & \multicolumn{1}{|c|}{ Nilestone Definition } & Date \\
\hline 1 & Issue Program Management Plan & December 1995 \\
\hline 2 & $\begin{array}{l}\text { Engineering Evaluation of TY Tank Farms Inact jve Miscel laneous Underground } \\
\text { Storage Tanks (IMUSTs) to Support the Control led, Clean, and Stable (CCS) } \\
\text { Program }\end{array}$ & January 1996 \\
\hline 3 & Engineering Evaluation of TX Tank Farms IMUSTs to Support the CCS Program & June 1996 \\
\hline 5 & Sampling and Analysis Plan for Tank BXR-011 & June 1996 \\
\hline 6 & Engineering Evaluation of BX Tank FarmS IMUSTs to Support the CCS Program & September 1996 \\
\hline 7 & $\begin{array}{l}\text { Issue Regulatory Compliance Plan } \\
\text { Integrity) }\end{array}$ & September 1996 \\
\hline 8 & $\begin{array}{l}\text { Complete Safety Evaluation or Revision to Preliminary Hazards Analysis for } \\
\text { Seven Additional Tanks }\end{array}$ & December 1996 \\
\hline 9 & $\begin{array}{l}\text { Engineering Evaluation of IMUSTs in Three Tank FarmS to Support the CCS } \\
\text { Program }\end{array}$ & Decmber 1996 \\
\hline 10 & $\begin{array}{l}\text { Engineering Evaluation of IMUSTs in Three Tank Farms to Support the CCS } \\
\text { Program }\end{array}$ & March 1997 \\
\hline 11 & $\begin{array}{l}\text { Engineering Evaluation of IMUSTs in Three Tank Farms to Support the CCS } \\
\text { Program }\end{array}$ & June 1997 \\
\hline 12 & Issue Sampling and Analysis Plans for Vapor Samples in Three Selected Tanks & June 1997 \\
\hline 13 & Obtain Vapor Samples from Three Selected Tanks & June 1998 \\
\hline 14 & Complete Video Scans of 36 IMUSTs & June 1998 \\
\hline 15 & Obtain Core Sample from One Tank & September 1998 \\
\hline 16 & Complete Tank Monitoring/Ventilation Upgrades & September 1998 \\
\hline 18 & Issue Tank Characterization Report & September 1998 \\
\hline
\end{tabular}

\subsection{Program Participant Roles and Responsibilities}

Major IMUST Program participants are depicted in Figure 1-5. The TWRS Environmental Engineering manager is the IMUST Program Manager responsible for directing and approving all engineering and characterization activities in the program. The Program Manager will interface with the RL Tank Operations Division. The Program Manager also has review and concurrence responsibility for documents and requests pertaining to the TWRS IMUSTs that are submitted to WHC TWRS management or to RL TWRS. Figure 1-5 also shows the relationship between the TWRS IMUST Program and the Transition Projects Integration Program Office (TPIP) and the Transition Projects Interface Control Working Group (ICWG). 
Table 1-5 provides a Responsibility and Accountability Matrix (RAM) for the major participants involved with Program organization. The TPIP has the responsibility for defining scope and integrating, facilitating, and evaluating the planning and performances of all projects performing work within the tank farms. These responsibilities are outlined in the RL TPIP Statement of Work and the TPIP Program Management Plan. The TP ICWG manages the Interface Control documents established among Transition Projects and resolves schedule and resource conflicts of work planned in the tank farms.

Table 1-5. Responsibility and Accountability Matrix for Inactive Miscellaneous Underground Storage Tanks.

\begin{tabular}{|c|c|c|c|c|c|c|c|c|c|}
\hline Manager & Organization & PMP & $\begin{array}{l}\text { Eng } \\
\text { Evais }\end{array}$ & $\begin{array}{l}\text { S\&A } \\
\text { P1ans }\end{array}$ & $\begin{array}{l}\text { Char } \\
\text { Plan }\end{array}$ & $\begin{array}{c}\text { Env } \\
\text { Docs }\end{array}$ & Mods & Sampling & PHA \\
\hline J. Kinzer & RL TWRS & A & & & & & & & \\
\hline A. Sidpara & $\begin{array}{l}\text { RL Tank Farm } \\
\text { Operations }\end{array}$ & G & $R$ & & $\mathrm{R}$ & A & $R$ & & $R$ \\
\hline C. Haass & $\begin{array}{l}\text { RL TWRS Environmental } \\
\text { Program }\end{array}$ & G & $\mathrm{R}$ & $R$ & $R$ & $\mathrm{R}$ & $\mathrm{R}$ & & $R$ \\
\hline R. Bacon & WHC TWRS & A & & & & & & & \\
\hline J. Wicks & $\begin{array}{l}\text { Tank Farms Transition } \\
\text { Projects }\end{array}$ & $R$ & A & A & A & & A & & $A$ \\
\hline W. Ross & $\begin{array}{l}\text { East Tank Farms } \\
\text { Operations }\end{array}$ & $R$ & $\mathrm{R}$ & $\mathrm{R}$ & $R$ & & $R$ & A & \\
\hline D. Reber & $\begin{array}{l}\text { West Tank Farms } \\
\text { Operations }\end{array}$ & $R$ & $R$ & $R$ & $R$ & & $R$ & A & \\
\hline C. Geier & $\begin{array}{l}\text { Environmental Cleanup } \\
\text { and Compliance }\end{array}$ & $\mathrm{R}$ & & & & A. I & & & \\
\hline R. Gustavson & $\begin{array}{l}\text { Environmental } \\
\text { Engineering }\end{array}$ & $R$ & $R$ & $\mathrm{R}$ & $R$ & $R$ & $\mathrm{R}$ & $R$ & $R$ \\
\hline R. Gustavson & IMUST Program & I & I & I & I & $\mathrm{R}$ & $\mathrm{R}$ & $R$ & $R$ \\
\hline L. Borneman & $\begin{array}{l}\text { TWRS Environmental } \\
\text { Compliance }\end{array}$ & $R$ & $\mathrm{R}$ & $R$ & $\mathrm{R}$ & $\mathrm{R}$ & & & \\
\hline R. Bilskis & $\begin{array}{l}\text { Transition Projects } \\
\text { Integration Program }\end{array}$ & $\mathrm{R}$ & $R$ & $\mathrm{R}$ & & & $\mathrm{R}$ & $R$ & \\
\hline G. Meyer & TWRS Retrieval & $R$ & $\mathrm{R}$ & & & $\mathrm{R}$ & $\mathrm{R}$ & & \\
\hline G. Dunford & TWRS Safety & & & & & & & & $\mathrm{R}$ \\
\hline 3. Thomson & $\begin{array}{l}\text { TWRS Tank Farms } \\
\text { Engineering }\end{array}$ & & & & & & A & & \\
\hline D. Leach & $\begin{array}{l}\text { WHC Safety Analysis } \\
\text { Engineering }\end{array}$ & & & & & & & & A \\
\hline J. Burton & $\begin{array}{l}\text { TWRS Tank } \\
\text { Characterization }\end{array}$ & & & A & $\mathrm{R}$ & & & I & \\
\hline B. Erlandson & $\begin{array}{l}\text { WHC Environmental } \\
\text { Compliance }\end{array}$ & & & & & $R$ & & & \\
\hline & WHC Projects & & & & & & $\mathrm{R}$ & & \\
\hline
\end{tabular}

A - Approval; R-Review; G - Guidance; I - Implementation 


\subsection{Assumptions and Conditions}

Major assumptions and constraints may significantly affect program management. and must be considered in program and project planning and execution. These assumptions and constraints are listed in Table 1-6.

\section{Table 1-6. Tank Farms Transition Projects Integration Program Assumptions and Constraints.}

\begin{tabular}{|c|l|}
\hline \hline Item & \multicolumn{1}{|c|}{ Assumption/Constraint } \\
\hline \hline 1 & $\begin{array}{l}\text { Quality management principles will be used in management, planning, and integration } \\
\text { activities. }\end{array}$ \\
\hline 2 & $\begin{array}{l}\text { System Engineering processes will be used to define and manage the program technica } \\
\text { baseline as a basis for traditional multi-year planning. }\end{array}$ \\
\hline 3 & Risk-based decision making will be used in program and project management processes \\
\hline 4 & $\begin{array}{l}\text { Technical and planning integration wi ll be provided among Tank Waste Remediation } \\
\text { Systems (TWRS) organizations and activities. }\end{array}$ \\
\hline 5 & $\begin{array}{l}\text { TWRS Quality Assurance and Environmental, Safety. and Health objectives wi } 11 \text { be } \\
\text { incorporated into project plans. }\end{array}$ \\
\hline 6 & $\begin{array}{l}\text { Stakeholder comments will be solicited on the TWRS Inactive Miscellaneous } \\
\text { Underground Storage Tank Program Management Plan. }\end{array}$ \\
\hline
\end{tabular}

The PMP includes the following sections:

Section 1.0, Introduction, summarizes the program purpose, scope, and program participant roles:

- Section 2.0. Planned Accomplishments, addresses IMUST Program objectives, including technical, cost, and schedule objectives:

- Section 3.0, Management Systems and Controls, depicts program work scope elements, participants, and relationships established to achieve program objectives:

- Section 4.0. Technical Systems and Controls, documents the overall approach used in establishing and controlling program baselines and integrating the technical project plans and measurement techniques; and

- Section 5.0. Administrative Systems and Controls, documents administrative support systems used in program work planning and performance and definition and oversight of projects assigned to the Program. 
WHC-SD-WM-PD-046, Rev 0

\subsection{PLANNED PROGRAM ACCOMPLISHMENTS}

Major IMUST Program products are associated with:

1. Engineering analyses and limited characterization in support of the CCS Program;

2. Tank modifications (as required).

The program provides a management structure and process that ensures costeffective and timely completion of IMUST program plans and activities that fully support the TWRS mission. The major IMUST Program services are project management. Systems Engineering (SE) analysis and integration, and technical guidance. Major products and services the IMUST Program expects to deliver over its lifetime, possibly through the year 2028, are summarized in Table 2-1.

Table 2-1. Inactive Miscellaneous Underground Storage Tanks Major Lifetime Accomplishments.

\begin{tabular}{|l||l||}
\hline $\begin{array}{l}\text { Work Breakdown } \\
\text { Structure Element }\end{array}$ & \multicolumn{1}{|c|}{ Accomplishment } \\
\hline \hline \begin{tabular}{l|l|}
1.1 \\
Program \\
Management
\end{tabular} & $\begin{array}{l}\text { Management of program activities that demonstrate efficient and effective: } \\
\text { 1) Implementation of program requirements: 2) Review and oversight of program } \\
\text { plan elements and activities; and 3) Integration of program activities with } \\
\text { other affected projects and activities. }\end{array}$ \\
\hline \hline $\begin{array}{l}1.2 \\
\text { Engineering } \\
\text { Analysis and } \\
\text { Field Support }\end{array}$ & $\begin{array}{l}\text { Preparation of engineering documents for: 1) Engineering evaluations of IMUSTs } \\
\text { for inclusion in the CCS Program; 2) Preparation of engineering support } \\
\text { documentation as required (i.e., Preliminary Hazards Analysis and/or other } \\
\text { safety evaluation or risk analysis); and 3) Preparation of engineering } \\
\text { assessments for tank characterization. surveillance and monitoring. }\end{array}$ \\
\hline \hline \begin{tabular}{l|l}
1.3 \\
Characterization
\end{tabular} & $\begin{array}{l}\text { Development of: 1) a Characterization Plan: 2) Sampling Analysis Plans: } \\
\text { 3) Data Quality Objectives; 4) Tank inspection plans/procedures: and 5) Tank } \\
\text { Characterization Evaluation. The evaluation of field data and sample results } \\
\text { wil1 also be performed. }\end{array}$ \\
\hline \hline $\begin{array}{l}1.4 \\
\text { Upgrades }\end{array}$ & $\begin{array}{l}\text { Oversight of engineering, design and installation of any modifications or } \\
\text { additions to existing tank equipment. }\end{array}$ \\
\hline \hline $\begin{array}{l}1.5 \\
\text { Regulatory } \\
\text { Support }\end{array}$ & Development and implementation of a Regulatory Compliance Plan. \\
\hline
\end{tabular}

\subsection{Requirements Application}

The IMUST Program will be requirements-driven. The requirements to be considered are those mandated by law. necessary to protect the environment, the public and worker health and safety, or those dictated by good engineering judgement. Other requirements will be reviewed to determine if they add value to the Program. Waivers will be sought for those requirements that do not add sufficient value.

The Program will implement quality management principles relative to identifying, evaluating, defining, accepting, implementing, tracking, and 
measuring accomplishment of IMUST engineering activities. Planning activities will focus on developing technical and administrative requirements to the level necessary to ensure a high degree of confidence that planned work can be accomplished within budget and on schedule. This objective requires that key decisions or hold points be defined and scheduled to ensure that Program benefits and risks are carefully considered prior to any significant expenditure of funds. Table 2-2 provides a summary of requirements objectives and Figure 2-1 provides a document hierarchy.

\section{Table 2-2. Summary of Requirements Objectives.}

\begin{tabular}{|c|l|}
\hline Objective & \multicolumn{1}{|c|}{ Requirement } \\
\hline \hline 1 & Apply value-added principles to define requirements. \\
\hline 2 & $\begin{array}{l}\text { Implement quality management principles relative to defining and managing } \\
\text { requirements. }\end{array}$ \\
\hline 3 & Evaluate Program benefits and risks at key decision points. \\
\hline 4 & $\begin{array}{l}\text { Plan and authorize only work that can obviously be accomplished and will meet } \\
\text { requirements. }\end{array}$ \\
\hline 5 & Include decision and hold points in plans and schedules. \\
\hline
\end{tabular}

Applying these concepts will require some level of rigor. This Program wi11 be closely integrated with the TPIP and will implement many of TPIPS processes and procedures. An SE approach will be adopted to provide the rigor necessary to select and apply the proper requirements. This will be done as part of the overa11 site project management system. It is recognized that some aspects of other project management processes must be used [i.e., DOE Order 4700.1. Site Management System (SMS), Activities Data Sheet (ADS) Process, and the MuitiYear Program Planning Process (MYPP)]. 
WHC-SD-WM-PD-046, Rev 0

Figure 2-1. Document Hierarchy.




Table 2-3 provides a summary of Key Schedule Drivers associated with the Master Schedule (Section 1.0. Figure 1-3).

Table 2-3. Summary of Key Schedule Drivers.

\begin{tabular}{|c|c|}
\hline Item & Schedule Driver \\
\hline 1 & Inspection and Monitoring of Tanks to Determine Leakage and Safety Risk Potential \\
\hline 2 & Characterization of Tanks Rated as High Potential Risk for Safety Issues \\
\hline 3 & Reevaluation of Risks Based on Inspection and Characterization Data \\
\hline 4 & $\begin{array}{l}\text { Inactive Miscellaneous Underground Storage Tanks (IMUSTS) Upgrades and/or } \\
\text { Stabilization }\end{array}$ \\
\hline 5 & $\begin{array}{l}\text { Retrieval andlor Resource Conservation and Recovery Act (RCRA) Closure for Single- } \\
\text { She } 17 \text { tanks (SSTS) and IMUSTs }\end{array}$ \\
\hline 8 & Support Completion of SST Retrieval/Closure Tri-Party Agreement Milestones \\
\hline 9 & $\begin{array}{l}\text { Support Reduction of Operations and Maintenance Costs Associated with Sin } \\
\text { Tank Farms }\end{array}$ \\
\hline
\end{tabular}

\subsection{Objectives}

The overal1 IMUST Program objective is to mitigate real risks to levels that:

1. Provide adequate protection to the workers and the public; and

2. Are acceptable to stakeholders.

A secondary objective is to achieve this level of risk reduction with the least possible cost and impact to other TWRS and site cleanup activities. To meet these overall program objectives, certain technical objectives must also be satisfied. These technical objectives are:

1. Implementation of TPIP technical guidelines, including SE processes, to plan. schedule, and manage technical work;

2. Provide a realistic and defensible assessment of relative safety risks posed by TWRS IMUSTS;

3. Provide a realistic and defensible assessment of leakage potential and environmental risk factors; and

4. Effective integration and management of the program schedule and resources.

\subsubsection{Systems Engineering}

The SE process will be merged with existing site project management processes to enhance overal1 effectiveness of planning and management of program activities. Appropriate applications of SE processes will be used to ensure the following:

- Program needs and technical objectives are well established:

- Proposed work is well-defined; 
- Management and technical basis for each work element are documented:

- Work activities are prioritized and controlled so resources are allocated to essential work;

- Work is performed and measured according to written authorizations:

- Technical objectives are met within the established cost and schedule;

- The IMUST Program activities are integrated with other programs:

- Management and technical interfaces are established;

- Decision points are established to allow for changes in technical direction when new information is obtained; and

- All decision points and work activities are documented, approved, and recorded.

\subsubsection{Program Statement of Work}

Tank Farm Transition Projects is establishing the IMUST Program to facilitate completion of all required operational and engineering work for transition of SST Farms to the Controlled, Clean, and Stable mode. The TPIP management function is to coordinate in-field and engineering support needs for infrastructure and hardware upgrades; and to incorporate upgrade-related activities into the Tank Farms Integrated Schedule. The IMUST Program wi 11 be integrated with all TWRS program activities at the planning, scheduling, and work execution stages through TPIP.

A summary of major program elements and subtasks for the TWRS IMUST Program is provided herein.

1. Baseline the Existing Data and Information:

- Conduct assessments of existing documentation and identify discrepancies and missing information:

- Finalize agreement on TWRS IMUSTS ownership;

$n$ Perform field walkdowns of cover blocks, risers, etc., and update facility drawings as required; and

- Evaluate historical data on waste characterization, tank integrity, and waste volumes for verification of tank contents and tank integrity.

2. Complete Initial Characterization and Défine Additional Characterization Requirements:

- Define characterization data and information necessary for evaluating the IMUSTs for inclusion in the CCS Program;

Complete initial characterization of high-risk tanks: and

- Evaluate existing Data Quality Objectives for applicability in defining data and information requirements necessary for continued management of the tanks in the post-CCS mode. 


$$
\text { WHC-SD-WM-PD-046, Rev } 0
$$

3. Define Regulatory Compliance Requirements.

- Develop a regulatory compliance strategy for negotiating requirements for post-CCS surveillance and upgrades and for retrieval/closure;

- Negotiate compliance agreement(s) with the Washington State Department of Ecology (Ecology) for the post-CCS mode;

- Develop an initial strategy for retrieval/closure of TWRS IMUSTs: and

- Negotiate future milestones with Ecology and the EPA for retrieval/closure of the TWRS IMUSTs.

4. Transition. TWRS IMUSTs to the CCS Mode.

- Identify requirements in the CCS Program applicable to IMUSTs;

- Determine IMUST safety analysis, characterization, inspection. stabilization, and/or upgrades activities required to satisfy CCS endpoint criteria;

- $\quad$ Determine requirements applicable to TWRS IMUSTs that are not within the scope of the SST Farm CCS plans;

- Complete IMUST activities necessary to meet CCS endpoint criteria, and provide appropriate documentation to allow transition of the SST Farms to CCS on schedule; and

- Transition TWRS IMUSTs, not directly associated with a tank farm, to a mode equivalent to CCS.

5. Perform Risk and Safety Ana lyses:

- $\quad$ Develop a safety evaluation for the seven additional TWRS IMUSTs not originally included in the Unreviewed Safety Question Determination (USQD) and PHA documents; and

- Evaluate tank inspection results and initial characterization data.

\subsubsection{Program Work Breakdown Structure}

The IMUST Program will be organized, defined, and tracked, using the programlevel Work Breakdown Structure (WBS). This PMP describes overail program management and technical functions. The WBS provides the best means for implementing PMP management and technical objectives.

The WBS Dictionary will provide a description of the activities, products, and milestones: and associated schedules and cost profiles. The WBS Dictionary will be revised to reflect changes and will be maintained in a current status throughout the program life.

\subsection{Schedule Objectives}

The IMUST Program schedule objectives are to:

1. Complete all activities required to meet the TWRS IMUST Program technical objectives within the time frame outlined in this PMP: and 
2. Status, measure, evaluate, trend, and report progress on the program schedule and milestones to support and facilitate Program objectives.

These objectives will be achieved by integrating al1 TWRS IMUST activities with a 11 other TWRS programs, and by developing and tracking progress against upper and lower level schedules. Figure 2-2 provides the three planned schedule levels.

Figure 2-2. Schedule Hierarchy.

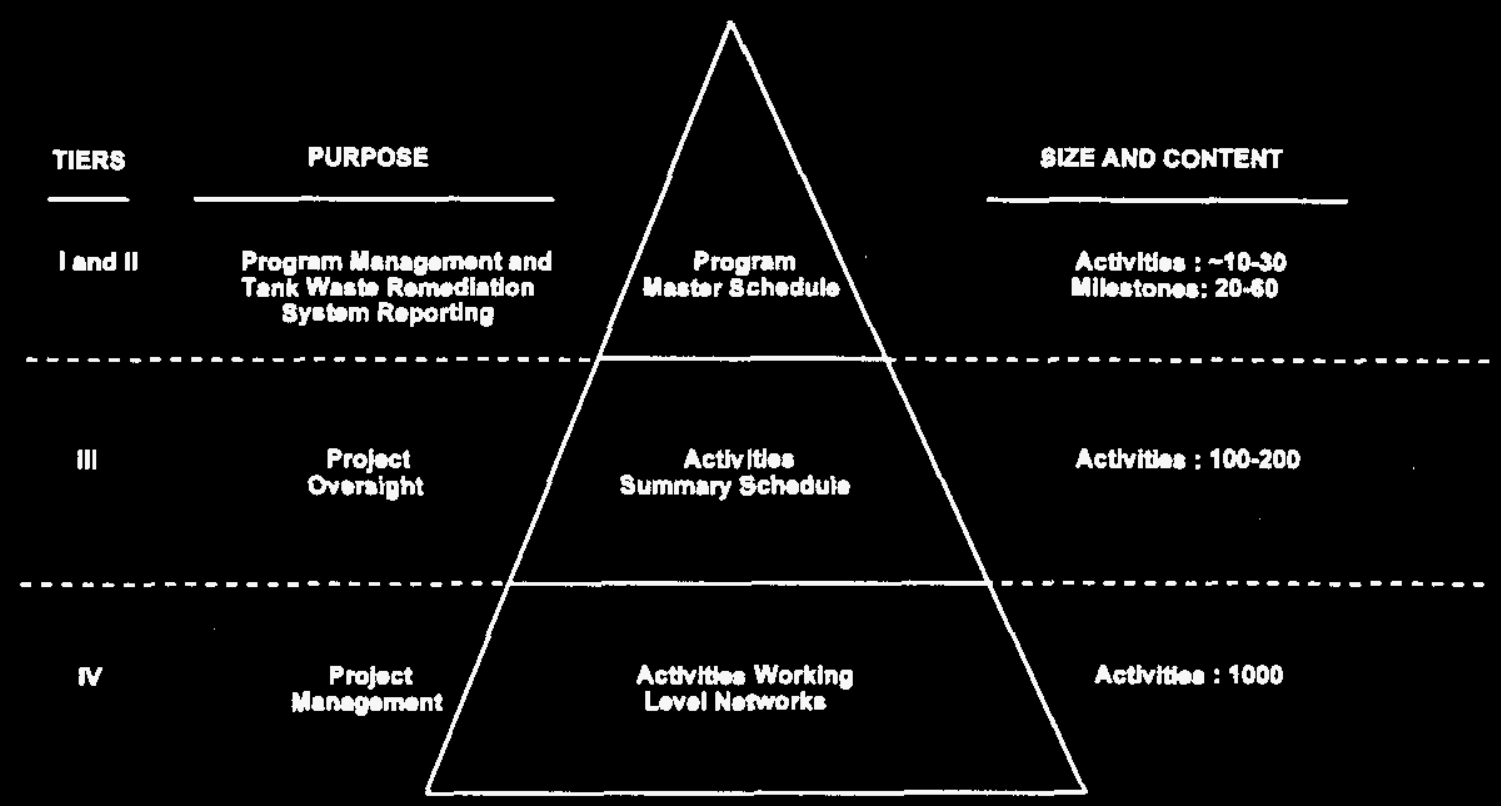

These schedules will be used for managing, oversight, and reporting purposes. In addition, a working level schedule wi 11 be developed, maintained, and merged into the Transition Projects Primavera schedule system, which wi 11 provide schedule and resource information to the TPIP Tank Farms System Tree database. Data analysis will provide planned and ongoing Tank Farms activities information to the Transition Projects ICWG for conflict resolution and resource leveling. Results of ICWG deliberations will feed back into the program schedule for modifications.

\subsection{Cost Objectives}

The IMUST Program has the following two cost objectives:

1. Develop realistic cost estimates for program and engineering projects activities, based on clearly defined requirements; and

2. Track and control costs of work to within approved costs.

These objectives will be accomplished through early development and implementation of definitive project plans and schedules and through excellent project management at all levels. 
The MYPP, which provides program and project cost planning, is updated annually and includes cost projections (cost profiles) for the current Fiscal Year (FY), 3-year period, 5-year period, and total project end (completion) costs. The FY 1996 MYPP cost profiles for the IMUST Program are provided in Section 1.0. Figure 1-2. Total estimated projected cost for the next three years is $\$ 5.8$ Million.

Cost control criteria, including monthly trending, cost estimating, status reporting, and performance measurements wi 11 be performed in accordance with DOE Orders 4700.1 and 1332.1A, the Hanford Financial Data System (FDS), and the SMS. A traceable and auditable path from cost baselines to mission requirements throughout will be established and maintained by the change control process.

\subsection{Communications Objectives}

The IMUST Program communication objective is to facilitate and maintain open. frequent, and effective communication among all participants and stakeholders. This communication will be both horizontal and vertical, to foster involvement, integration, and interaction between the TWRS IMUST Program participants, other TWRS Projects (i.e., characterization, retrieval, etc.), and other stakeholders.

These efforts wi 11 be supported with the Integration and Baseline Management Plan of the TPIP Office. This plan identifies methods for managing TPIP's interfaces with other TWRS programs. The Public Involvement Plan, included in the Integration and Baseline Management Plan, supports the TPA Public Involvement Plan and other activities of interest to stakeholders. The TP ICWG, is also included in the management plan, and supports communication among projects on scheduling and resources for executing tank farm activities.

\subsection{Integration Objectives}

The IMUST Program wi11 integrate with other activities in the TWRS organization through the TPIP Office. Figure 2-3 depicts the relationship of the TWRS TPIP Office to all other interfacing organizations. The IMUST Program is a part of the TWRS Programs. Table 2-4 depicts the assigned functions of the key interface organizations. 
Figure 2-3. Key Interface Organizations.

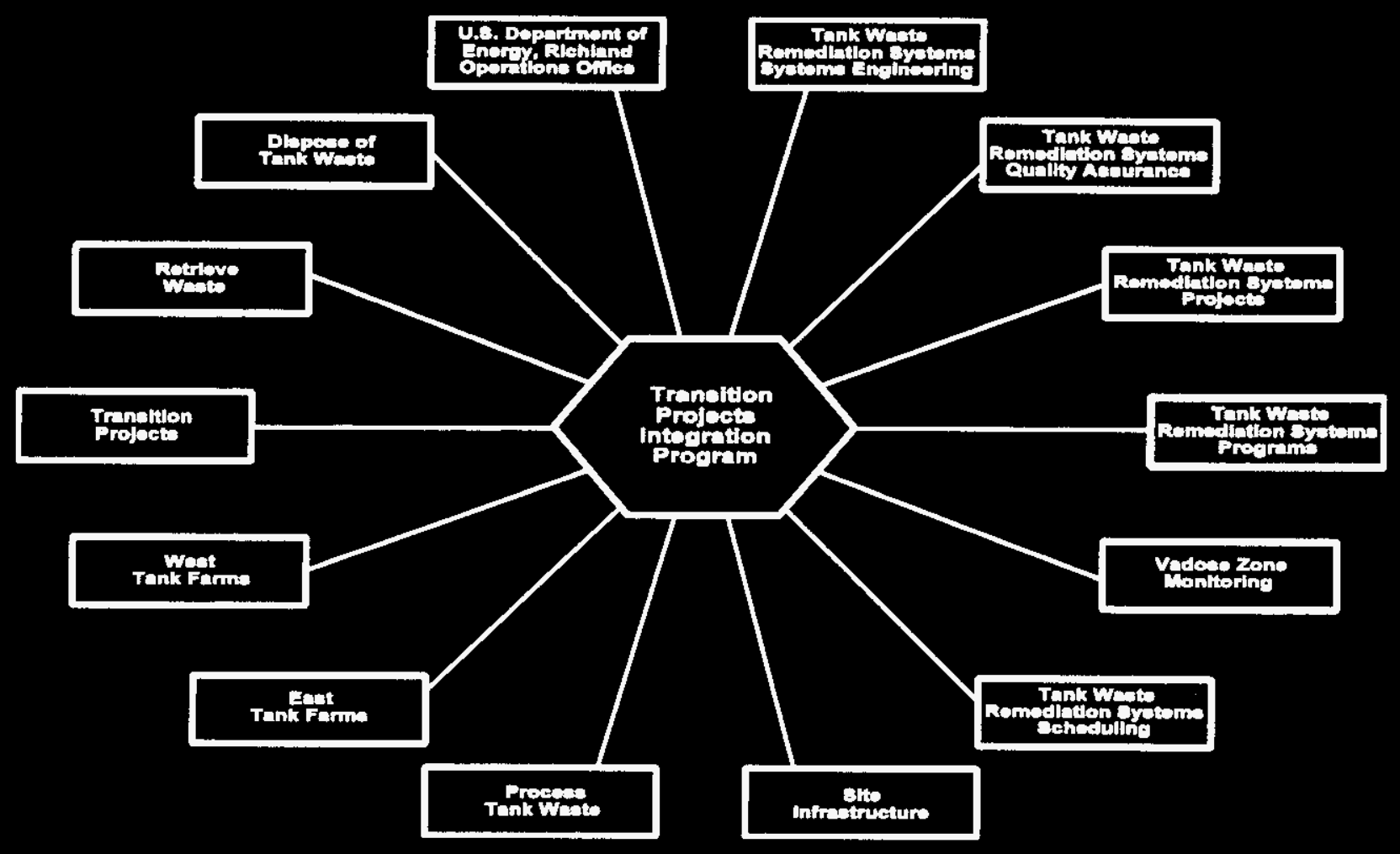


WHC-SD-WM-PD-046, Rev 0

Table 2-4. Key Interface Organizations Assigned Functions.

\begin{tabular}{|c|c|}
\hline Organization & Interface Function \\
\hline $\begin{array}{l}\text { Richland Operations } \\
\text { Office }\end{array}$ & Client Statement of Work Direction, and Oversight \\
\hline Transition Projects & Imnediate Up-Line Management \\
\hline West Tank Farms & Owner and Operator of West Tank Farms \\
\hline East Tank Farms & Owner and Operator of East Tank Farms \\
\hline Process Tank Waste & $\begin{array}{l}\text { Owner and Operator of Tank Farms Evaporator and Other Tank Waste } \\
\text { Processing Facilities }\end{array}$ \\
\hline Vadose Zone Monitoring & Instrumentation and Electrical Requirements \\
\hline Retrieve Waste & Piping. Electrical, Ventilation, and Instrumentation Requirements \\
\hline Dispose of Waste & Piping, Electrical, Ventilation, and Instrumentation Requirements \\
\hline $\begin{array}{l}\text { Transition Projects } \\
\text { Interface Control Working } \\
\text { Group }\end{array}$ & $\begin{array}{l}\text { Client for All Tank Farms Upgrade, Maintenance, and Operations Projects } \\
\text { and Activities Scheduling and Resource Loading Issues Identification, } \\
\text { Definition, and Resolution }\end{array}$ \\
\hline $\begin{array}{l}\text { Tank Waste Remediation } \\
\text { System (TWRS) Scheduling }\end{array}$ & $\begin{array}{l}\text { Client for All Transition Projects Integration Program (TPIP) Projects and } \\
\text { Activities Scheduling and Resource Loading Information }\end{array}$ \\
\hline TWRS Programs & $\begin{array}{l}\text { Client for All TPIP Projects and Activities Planning and Budgeting } \\
\text { Information(Including IMUST Program) }\end{array}$ \\
\hline TWRS Systems Engineering & Source of TWRS Systems Engineering Policies, Processes, and Requirements \\
\hline TWRS Quality Assurance & $\begin{array}{l}\text { Source of TWRS Qual ity Assurance Policies, Program, Procedures, Guidance. } \\
\text { Surveillances, and Audits }\end{array}$ \\
\hline TWRS Projects & $\begin{array}{l}\text { Line Management of TPIP Projects and Coordinator. Cooperator, and Support } \\
\text { of TPIP Project Management Objectives. Strategies. Plans, and Controls }\end{array}$ \\
\hline Site Infrastructure & $\begin{array}{l}\text { Owner and Operator of Roads, Electrical, Steam, Rajlroads, Electrical, } \\
\text { Communications, and Other Site Infrastructure Facilities and Systems }\end{array}$ \\
\hline
\end{tabular}




\subsection{MANAGEMENT SYSTEMS AND CONTROLS}

Program management systems and controls will be used or developed to ensure satisfying IMUST Program management objectives are met in the following:

- Front-end planning and budgeting;

- Performance management and reporting;

- Cost and schedule controls; and

- Integration management.

This section of the PMP provides a discussion of the management system key elements.

\subsection{Organization}

The general IMUST Program philosophy is to organize in such a way as to effectively facilitate the performance of the major program function, which is to stage the IMUSTs so that they can be held and managed until means have been decided for their final disposition under an appropriate RCRA closure plan. The organization, therefore, follows the WBS out ine provided in Figure 1-4. and key functions of each organizational element follows the Major IMUST Lifetime Accomplishments provided in Table 2-1. Program administration is implemented under Program Management (WBS 1.1): operations, safety, tank engineering, environmental engineering and quality assurance are implemented under Program Support (WBS 1.2); sampiing, analysis, and tank condition evaluations are implemented under Characterization (WBS 1.3); any possible IMUST Tank modifications are implemented under Tank Upgrades (WBS 1.4); and Regulatory Activities (WBS 1.5). The organization and management processes described herein are focused on achievement of the major program functions.

Figure 3-1 provides a list of systems, controls, and reporting requirements for the IMUST functional responsibilities. Appendix C Planning Matrices Inactive Miscellaneous Underground Storage Tanks, depicts the key program interfaces in a chronologically ordered series of diagrams. 
Figure 3-1. Systems, Controls, and Reporting Requirements for the Inactive Miscellaneous Underground Storage Tank Program Functional Requirements.



Notea:


Roverse flow of Feodbackinformation is implielt 


\subsubsection{Tank Waste Remediation System Environmental Engineering and Inactive Miscellaneous Underground Storage Tank Program Relationships}

Figure 3-2 provides a TWRS Environmental Engineering summary organization chart. As the dashed lines in Figure 3-2 indicate, the IMUST Program Manager interfaces with the Transition Projects Integration Program. In conducting the interface process, a key responsibility will be the coordination and issue resolution functions with the Maintenance, Evaporator, and East and West Area Transition Projects.

\subsubsection{Inactive Miscellaneous Underground Storage Tank Program Office}

The top-level organization for the IMUST Program is provided in Section 1.0, Figure 1-5. There are five key functions reporting directly to the IMUST Program Manager.

Figure 3-2. Tank Waste Remediation System Environmental Engineering Summary Organization Chart.

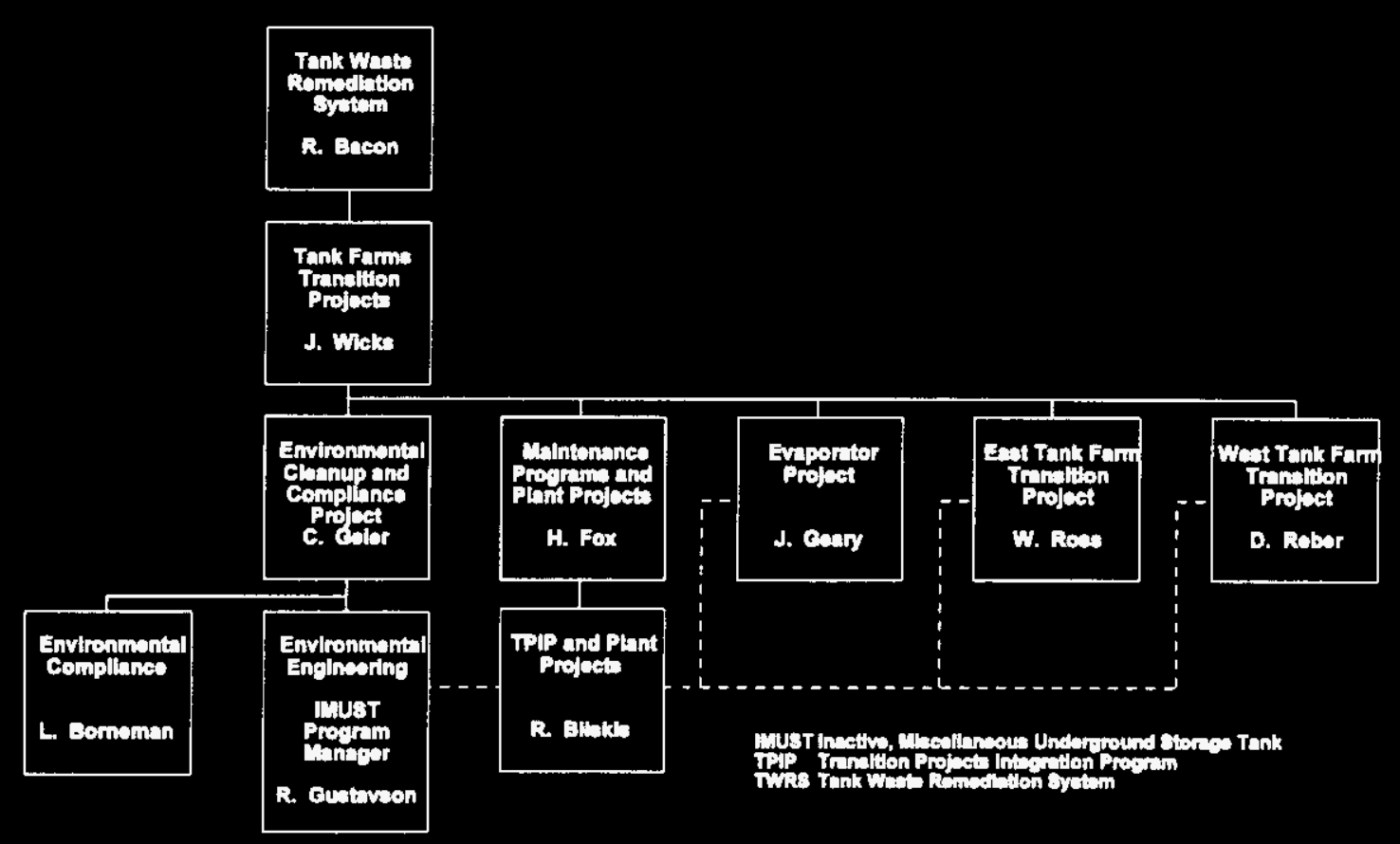

Lead individuals will be responsible for the five second-level functions of Program Management. Program Support. Characterization. Upgrades, and Regulatory Activities. In this capacity, Function Leaders will be responsible for development and implementation of plans, schedules, work scopes, technical approaches, milestones, and deliverables; and establishment of various policies and procedures to facilitate uniform practices and reporting in IMUST activities within TWRS Environmental Engineering. Sections 3.2 through 3.10 provide further detail describing these key tasks. 
WHC-SD-WM-PD-046, Rev 0

\subsubsection{Responsibilities, Authorities, and Accountabilities}

Figure 1-6 provides the IMUST responsibilities, authorities and accountabilities, based on the organization provided in Section 1.0. Figure 1-5. The IMUST Program Manager has overa 11 responsibility to manage, review. and approve IMUST plans and policies. Function, Task, and Subtask Leads are responsible and accountable for executing assigned work defined by the WBS.

\subsection{Planning and Budgeting}

The Hanford planning process includes involvement in mission statements and analyses; and strategic, multi-year (MY), fiscal-year (FY) and cost account (CA) planning. Budgeting is required for MY. FY, and CA planning phases. Planning and budgeting management and direction flows down to the IMUST Program assigned account manager from RL and TWRS management. The SE disciplines and processes are supporting tools for the planning and budgeting phases (i.e., results of a tank characterization are valuable in initial project and scope definition). Appendix $C$ includes matrixes for each of the organization processes presented herein.

\subsubsection{Systems Engineering}

The SE disciplines, processes, and analytical tools are critical planning phase elements that support the IMUST Program Manager's team planning efforts. Within the IMUST Program. SE is implemented through the TPIP Systems Engineering Management Plan (SEMP). This implementation allows the IMUST Program Manager to better use key SE processes (i.e.. Mission Analysis:

Functions and Requirements Analysis and Allocations; Evaluation and Decision Support: Synthesis: and Verification and Validation). These processes have valuable support applications throughout other phases of the IMUST Program (i.e., Work Authorization and Control, Scheduling and Budgeting, Program/Project Execution, and Performance Analysis and Reporting).

\subsubsection{Multi-Year Program Planning}

The MYPP is prepared annually and provides the longer range and strategic foundation for the FYWP. The RL and TWRS planning parameters and directions flow down to the IMUST Program Manager, who in turn disseminates the information to assigned project, cost account, and task managers. Through support from applying SE disciplines and processes, a bottom-up planning assessment is fed back into the MYPP preparation.

This bottom-up technical baseline information input is even more critical in preparing the FYWP. This iterative planning process develops IMUST Program, projects, and activities technical objectives and scheduling/budget

parameters. At the TWRS level, the program/project plans are revised to be in concert with expected available resources and funding. The finalized plan documents are presented to RL for approval. The critical document at this point is the FYWP. Once approved, WHC and TWRS contracts pass authority down to the IMUST Program Manager with the agreed scope, budget, deliverables, and major milestones. 


\subsection{Work Authorization and Control}

After FYWP approval, WHC and TWRS pass authority to the IMUST Program Manager to distribute scope and budget to the IMUST Program. projects, and activity Cost Account Managers (CAMs). At the WHC or TWRS level management. reserve may be established for the IMUST Program (used for in-scope discretionary funding by the IMUST Program Manager).

\subsection{Scheduling and Budgeting}

The assigned project and activity CAMs prepare a Cost Account Plan (CAP). This CAP details resources (people, material, capital, services, etc.) and schedules to accomplish the scope of work for the FY.

The TWRS business support prices out the CAP on a monthly basis and inputs into the WHC FDS. The IMUST Program, projects, and activities planning prepares the schedules for the CAP in the Primavera System. Earned value methods are also entered into the system. A Tier III schedule (see Figure 22). including all the CAP inputs, is prepared for the IMUST Program level. ensuring that Tier III milestones are in consonance with the Tier I and II schedules. The Tier III schedule becomes the IMUST Program, projects, activities performance measurement baseline. The budget spread for the CAPs becomes the cost performance measurement baseline. The combined schedule/cost baselines are used for performance measurements.

The integrity of the cost/schedule/technical performance baseline is dependent on effective change management and control. The RL-directed baseline changes flow down through contracts. The WHC-originated baseline changes require using the change process, which may include the formal change board. Class I changes require RL approval.

\subsection{Program/Project Execution}

The Cost Account Manager (CAM) or Task Manager (TM) has responsibility for the day-to-day CAP execution. In addition, two other critical responsibilities are executed during this phase:

1. Periodic (weekly/monthly) evaluation and reporting of results; and

2. Identify problems or issues to be resolved: or on the positive side, highlight opportunities (cost savings, methods improvements, etc.) for consideration.

The IMUST Program, project, and activities management and staff supports the CAM/TM during this phase by managing and facilitating program. project, and task interfaces not resolved at the CAM/TM level. Support for the CAM/TM can also be enhanced by MBWA (Management By Walking Around), which communicates personal interest and provides direct observance of activities and results. 


\subsection{Performance Measurement and Reporting}

The foundation for IMUST Program, projects, and activities performance measurement will be accurate time/cost keeping and schedule statusing. Actual costs reflected against budget are available through the FDS. Scheduiing performance will be assessed through the Primavera scheduling system and special schedule updates. In addition, earned value will be determined.

The IMUST Program, projects, and activity CAMs, supported by the IMUST Program planners and business manager representative, will be key to the effective bottom-up flow of performance information and analyses. Cost/schedule variances that exceed threshold limits require written assessment. Verification and validation, an SE process, will be used to evaluate technical objectives. Process metrics will be used to evaluate trends.

\subsection{Program/Project Closeout}

By completion, truncation, or termination, the programs and projects end. It is important that this phase be managed efficiently and effectively. A program may require contractual closeout, direction, or like a project, be triggered by the last milestone or deliverable. This is a period of final accountability or results against plan, program/project property, documentation completeness, and submission of closeout report or closeout document, as required.

\subsection{Records and Information Management}

The IMUST Program, projects, and activities will implement TWRS documents/records management requirements. Records management procedures for the IMUST Program are included in the TPIP Records Management Plan.

The IMUST Program records management wi 11 be implemented by:

1. Use or augmentation of existing systems and depositories for documentation:

2. Process and dissemination of documentation in compliance with contractual requirements, and interface capability with Data and Database Management support; and

3. Perform critical and technical evaluations for software applications, mindful that the objective is to use existing or off-the-shelf software, rather than developing and writing CODE from scratch.

\subsection{Communication Management}

Communications within and among IMUST projects and related TWRS projects and infrastructure elements, is of the essence. The TWRS and IMUST Program procedures are provided in the IMUST Program administrative procedures and include logging of incoming and outgoing correspondence, records of telephone conversations, and records of meetings and conferences). These procedures apply to meetings, conversations, or discussions that result in decisions 
concerning scope, schedule, and/or budgets of the IMUST Program. Upgrade Projects, and other RL, WHC. or TWRS programs and projects related to, or potentiaily impacting. TWRS Environmental Engineering. IMUST Program.

Communication among IMUST Program projects and activities must be logged, placed in appropriate records, and distributed in accordance with TPIP Administrative procedures.

Communications among IMUST Program, projects, activities, Transition Projects, TWRS Management, and Site infrastructure elements wi 11 be planned, documented, and coordinated with the IMUST Program Management function. All written communications with TWRS or RL management, concerning plans, data, conclusions, status reports, and other similar IMUST Program, projects, and activities information are iimited to materials that have been reviewed and cleared through the IMUST Program Office. The IMUST Program procedure for review and peer reviews will apply in these cases. The IMUST Program. projects, and activities reports will follow the format provided in the TPIP Administrative procedures.

Site infrastructure and support organizations and systems exist to provide, maintain and upgrade, as required, the basic telecommunication, data communication, video and photo/graphic tools supporting the communication process. Special IMUST Program, projects, and activities requirements beyond these normally available "tools" will be identified. justified, and coordinated through the IMUST Program Management function. The "form, fit, and function" specifications for IMUST Program, projects, and activities communication wi11 be stipulated by the IMUST Program Manager through procedures. Frequency of reporting or formal submittals wi 11 also be controlled.

A11 IMUST Program, projects, and activities participants are expected to listen attentively. communicate clearly and concisely in a timely manner, and keep the correct team members informed.

\subsection{Integration Management}

Integration and interface management are the responsibilities of every IMUST Program, project, and activity. Responsible staff and managers are expected to know other projects and activities that will affect their work and which their work will affect. They are also required to ensure that potential effects are planned and controlled to minimize or preclude problems.

Integration of IMUST Program, projects, and activities will be managed by the Program Management element of the IMUST Program. Integrations of a11 IMUST projects and activities will be managed and facilitated by the TPIP and the Transition Projects ICWG, which reports to the TPIP manager. The TPIP Integration and Baseline Management Plan outlines the process and procedures for general integration and function of the ICWG. The TPIP SEMP out 7 ines the process and procedures for identifying, defining, and controlling interfaces related to the technical baseline.

The control over the integration process is accomplished by reviewing and authorizing the day to day or weekly assigned tasks that are part of, interface with, or impact the program. When concerns/issues/problems arise of 
WHC-SD-WM-PD-046, Rev 0

an interface or integration nature that are not timely solved at the first level, elevation to the TPIP level and then the ICWG is required. These are then subject to regular program/project reviews, corrective actions, and tracking through commitment contro1. 


\subsection{BASELINE SYSTEMS AND CONTROLS}

Development of sound and defensible baselines is essential to successfur management of IMUST Program. Proposed proposed baseline systems and controls provide work-based inputs to the total planning process. The IMUST program management process is predicated on a common understanding of project needs (or "mission"). identification of activities necessary to meet those needs. identification of requirements associated with each activity, and formalization of requirements into specifications for the various items associated with project performance. These items (or "products") are the basis for the project WBS. During execution of possible IMUST modifications, technical plans and procedures outlined in the TPIP SEMP will be used as work controlling documents. The TPIP Technical Data Management Plan wi 11 control and manage data generated during the implementation phase. The TPIP Project Controls (configuration management, quality assurance management, interface management, and technical peer review management) will be used throughout IMUST upgrade project life-cycles to deal with changes and to ensure quality. Figure 4-1 provides a general logic diagram for planning, baseline development, implementation, and control of technical systems for possible IMUST modifications. Adoption and implementation of TPIP management and systems engineering policies, plans, and procedures will preclude duplication of effort, and enhance integration and interface opportunities.

Figure 4-1. Planning and Baseline Development.



\subsection{Technical Basel ine Management}

The TPIP systems engineering process will provide the means to define the technical baseline for any IMUST modifications. Figure 4-1 illustrates the basic products and steps in the systems engineering process which will lead to requirements driven technical baselines. Technical baselines will also provide the basis for associated cost and schedule baselines for each projects. Integrated Project Baselines will be the combination of the Technical Baselines with corresponding Cost and Schedule Baselines. The SE criteria form the basis for developing and maintaining the technical. cost and 
schedule baselines. The following eight fundamental criteria relate to the exercise of good engineering and management practices.

- Clearly Identified System: The system under consideration will be understood and bounded.

- Clearly Identifjed Management Decision Authority: Lines of responsibility and authority for making decisions on the system will be documented.

- Clearly Identified Management Methodology: Management controls, decision analysis and other attributes of the management and engineering methodology wi 71 be defined and documented.

- Documented Baseline: A baseline for the selected system that integrates technical requirements, schedule and cost elements will be documented.

- Baseline Validation: Baselines will be capable of being validated.

- Demonstration of End Products: The system end products wi 11 be capable of demonstrating fulfillment of the measurable requirements allocated to the system.

- Identification and Management of Interfaces: Interfaces among Transition Projects, TPIP. TWRS, RL contractors, regulators and stakeholders will be identified and managed.

- Clear and Simple Process to Manage Change: A practical configuration management plan and program and an appropriate change control process wili be established to manage change.

Any IMUST modification technical baseline will be predicated on Hanford Site, TWRS, and Transition Projects mission objectives. Development of technical base 7ines will be in accordance with DOE/RL -95-12, "Tank Waste Remediation System Systems Engineering Standard" as interpreted and implemented by TPIP. Since the SE process is iterative. inputs may be received at any time. However, once a baseline has been established, changes will be approved through established configuration management procedures.

The technical information generated to establish technical baselines will clearly define the scope of work for a project. In addition, technical baselines will provide the information necessary to link the baseline to both higher and lower level baselines within the overall TWRS mission. Technical products generated through the systems engineering process aid in the evolution of a technical baseline. These products are generated in a logical manner, and have the common purpose of satisfying the mission objectives.

Implementation of the TPIP systems engineering process steps will ensure we1]managed design processes that provide quality products, which can be clearly traced to stated missions and requirements.

\subsection{Configuration Management}

As development of any IMUST modifications proceed, the technical baseline will be established and integrated with cost and schedule baselines. Changes will 
WHC-SD-WM-PD-046, Rev 0

be implemented in a manner that ensures all impacted projects and activities are informed and that these projects and activities participate in the impact analysis as outlined in the TPIP Configuration Management Plan. The configuration management process will ensure disciplined control; configuration of products; and that products and documents are labeled. changes are managed, and accountability is maintained.

When changes to the technical, schedule and/or cost baselines of an IMUST upgrade project are required, they must be documented and reviewed for potential impacts to other baselines. Use of the TPIP change control process will assure that management responsible for the impacted systems or projects (especially those outside of the IMUST Program) have responded.

The TPIP Configuration Management process wi1l apply to IMUST Program technical and management review, approval, and surveillance of technical baseline documentation throughout IMUST project life cycles. It will ensure the integrity and internal consistency of technical baselines including requirements, functional and physical configurations, and documentation. Technical baseline documentation includes, in part, functions and requirements definitions, specifications, engineering records and design documents (e.g., hardware and facility drawings; interface control documents; process and software descriptions). The controlled documentation may be in the form of hard-copy or electronic documents, databases and models as specified in the TPIP Configuration Management Plan.

Configuration management will also be used to control changes of any IMUST modifications cost and schedule baselines. Integrated basel ine change control includes assessment of schedule and cost impacts of proposed technical baseline changes and impacts on the technical baseline of proposed schedule and cost changes.

Applicable configuration management requirements will be reflected in IMUST upgrade project plans and implemented in management and engineering procedures.

\subsection{Interface Management}

The IMUST Program interface control process will ensure that software, processes, information, parts, equipment, and systems fit and function together. Formal interface control documents (ICDs) are required between major system elements and between lower-level systems elements where different projects or organizations are involved. An ICD is the design and management tool formalizing an agreement between two or more entities. Assigned projects will have in place internal controls capable of satisfying the following criteria:

(1) Define and document interface requirements:

(2) Assign lead responsibility for each interface;

(3) Coordinate the pertinent variables for interfacing processes or operations (e.g., waste types, quantities, rates) and the designs for facilities, hardware, software and information: and

(4) Establish appropriate interface control documentation. 
WHC-SD-WM-PD-046, Rev 0

The development of ICDS is a continuous process that will be initiated in the early stages of any IMUST modifications planning cycle and wi11 define the common boundary between two or more entities. Interfaces will be defined through project Interface Control Working Groups (ICWGs). Within these working groups, representatives from both sides of an interface will develop documentation that establishes the requirements to which the interface wil1 be designed and developed. This documentation is outlined in the TPIP SEMP and the guidelines established in the TPIP Integration and Baseline Management plan. Inter- and Intra-project interfaces will be tracked and measured.

\subsection{Quality Assurance Management}

Any IMUST Program modifications will plan and perform their missions under existing Washington Administrative Codes (WAC) and TWRS QA Plans. The Quality Assurance Manua 1. WHC-CM-4-2, provides the WHC Qual ity Assurance Program requirements for the organizational structure, functional responsibilities. levels of authority, interfaces, and lines of communication for activities affecting quality. This procedure includes software QA requirements (QR 19.0 Rev 1).

Computers, including computer software used for TWRS applications are significant to occupational, environmental, on-site or off-site safety. quality of the company's reputation, or represent a high dollar value impacts. These systems are sufficiently important to require independent verification. and therefore, are subject to the requirements of $Q R$ 19.0 which establishes the WHC QA requirements for the development acquisition, use, modification, and configuration management of software used in computer systems.

Quality Assurance Requirements, DOE Safety Rule 10 CFR 830.120, states that a contractor responsible for a nuclear facility shall develop and submit for approval by DOE a QA Program for the work.

The WHC QA Program and Implementation Plan, Implementation of Tit le 10 Code of Federal Regulations, Part 830.120. WHC-SP-1131, Rev 0, identifies the TWRS Implementation Plan Action Items which involved the generation and revision of as-built drawings; updating TWRS organizational and program documents:

tracking the condition/age of materials/equipment; and reconstruction of design bases for existing, active facilities.

The TWRS Qua7ity Assurance Manua 7, WHC-CM-6-50 contains supplementary details for implementing the management control systems described in WHC-CM-6-34, "Quality Management Plan" issued by TWRS Division Executive Vice President.

\subsection{Technical Procedures and Plans}

The IMUST Program projects will implement technical procedures and plans for the TWRS organization given in the TWRS Administrative Manual. WHC-IP-0842, volumes I thru VII. The contents of each volume are listed in Table 4-1. 
Table 4-1. Tank Waste Remediation System Technical Procedures.

\begin{tabular}{|c|c|}
\hline Volume & Titles Included \\
\hline I - Administration & $\begin{array}{ll}\text { 1.0 } & \text { Programs/Plans } \\
2.0 & \text { Management/Administration } \\
3.0 & \text { Charters } \\
4.0 & \text { Safety/Security } \\
5.0 & \text { Quality Assurance } \\
6.0 & \text { Quality Assurance } \\
\end{array}$ \\
\hline II - Operations & $\begin{array}{ll}\text { 1.0 } & \text { Programs/Plans } \\
2.0 & \text { Management/Administration } \\
3.0 & \text { Access Control } \\
4.0 & \text { Conduct of Operations } \\
5.0 & \text { Waste Tank Monitoring } \\
\end{array}$ \\
\hline III - Training & 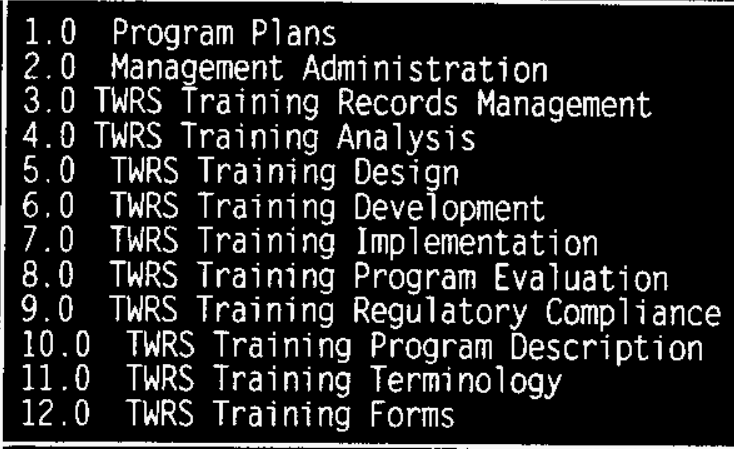 \\
\hline IV - Engineering/Modifications & $\begin{array}{ll}\text { 1.0 } & \text { Programs/Plans } \\
2.0 & \text { Management/Administration } \\
3.0 & \text { Configuration Management } \\
4.0 & \text { Engineering Documents } \\
5.0 & \text { Safety } \\
\end{array}$ \\
\hline V - Maintenance/Production Control & $\begin{array}{l}\text { 1.0 Program Plans } \\
2.0 \text { Management/Administration } \\
3.0 \text { Material Control/Procurement } \\
\text { 4.0 Safety } \\
5.0 \text { Procedures/Training } \\
6.0 \text { Configuration Management } \\
\text { 7.0 Work Control } \\
\end{array}$ \\
\hline VI - Environmental & $\begin{array}{ll}\text { 1.0 } & \text { Programs/Plans } \\
2.0 & \text { Management/Administration } \\
3.0 & \text { Reporting } \\
4.0 & \text { Solid Waste } \\
5.0 & \text { Stack Monitoring } \\
\end{array}$ \\
\hline VII - Radiological Control & $\begin{array}{ll}\text { 1.0 } & \text { Programs/Plans } \\
\text { 2.0 } & \text { Management/Administration } \\
3.0 & \text { Radiological Containment } \\
4.0 & \text { Contamination Control } \\
\end{array}$ \\
\hline Tank Waste Remediation System & \\
\hline
\end{tabular}

\subsection{Technical Data Management}

The IMUST Program and projects will manage technical data in accordance with Document Control and Records Management Manual. WHC-CM-3-5, as implemented by TPIP. This includes records management requirements and responsibilities. including program objectives, contract agreements, and restrictions affecting disposal requirements. This manual provides requirements and procedures 
necessary for maintaining record and non-record information that is produced in a variety of formats. WHC has a comprehensive records management program to ensure that important and necessary information is properly identified and easily retrieved when needed; and information is disposed of when it no longer serves a useful purpose.

The WHC Records management Program is established by WHC-CM-1-1, Management Policies. MP 3.5 "Document Control and Records Management," and WHC-CM-1-3. "Management Requirements and Procedures: MRP 3.3. Records Management Program," and applies to all records produced or acquired by WHC employees. subcontractors, and/or temporary consultants. Managers are responsible for ensuring that records maintained by their organization are handled in accordance with requirements in WHC-CM-3-5.

\subsection{Technical Peer Review Management}

IMUST Program and projects will manage peer reviews in accordance with WHC guidelines as implemented by TPIP. Reviews will be planned and results will be documented and, where necessary, tracked to closure.

Formal design review process and related documentation are described in WHCCM-6-1, EP-4.1. WHC-IP-1026. Standard Engineering Practices. Appendix H. Rev. 0 . External Peer Reviews provides guidance on when an external peer review is used and what it should evaluate and report on for documented engineering/scientific activities prepared by or for WHC. 
WHC-SD-WM-PD-046, Rev 0

\subsection{ADMINISTRATIVE SYSTEMS AND CONTROLS}

In support of the IMUST Program and projects, administrative systems are comprised of Security. Environmental Health and Safety (ES\&H), Personne], Contracts. Procurement, Database Management. Property Management, Subcontract Control, and Commitment Control. Each of these areas has existing plans, procedures, and controls, and the IMUST Program and projects will ensure proper interface and compliance with them and any augmenting TPIP specifics.

\subsection{Security}

Appropriate TWRS WHC security requirements (WHC-IP-0842, Vol I) wi11 be followed. This task is basically one of coordinating within the IMUST Program and liaison outside the program. Issues, concerns, and requests for support will be channeled through the IMUST Program Support Function.

\subsection{Environmental Health and Safety}

IMUST Program and project activities will be planned and executed in accordance with policies and procedures of the TWRS ES\&H plan. Each individual is responsible for awareness of, and compliance with, regulations and good working practices. Periodic training sessions and surveillance will provide knowledge necessary for a successful program.

\subsection{Personne1}

IMUST Program and project staff will be managed in accordance with WHC personnel policies and practices. IMUST Program personnel are assigned to the TWRS Environmental Engineering Manager, and assigned project staff are assigned to TWRS projects organization. Projects are matrixed to the IMUST Program and IMUST Program Management wi11 provide input to key project staff performance evaluations.

\subsection{Contracts}

The program manager or designee will be assigned the key task of interfacing with the contracts administrator assigned to support IMUST Program subcontracting. Working cooperatively together, appropriate contractor requirements for the program will be met.

\subsection{Database Management}

The IMUST Program and projects will manage databases in accordance with the TPIP Data Management Plan. The IMUST Program will oversee the TPIP plan's implementation to ensure efficiency, consistency data quality and control. 
WHC-SD-WM-PD-046, Rev 0

\subsection{Property Management}

A11 IMUST Program and projects-acquired property wi11 be inventoried, tagged, and managed according to RL and WHC requirements. Audits wi 11 be performed regularly to ensure proper control.

\subsection{Subcontracts Control}

The subcontract specialist assigned to the IMUST Program will control issuance of subcontracts, negotiate scope and cost in cooperation with assigned technical administrators, review and approve invoices, and ensure that deliverables are obtained before the subcontract is closed out. Subcontract activities will be conducted in accordance with WHC documented subcontracting procedures.

IMUST projects wi11 execute subcontracting under the oversight of the TWRS Projects organization. However. planned subcontracting activities wi 11 be reviewed and integrated with other transition projects activities through the TPIP Integration and Baseline Management element and the TP ICWG function.

\subsection{Commitment Control}

The IMUST Program will use existing, onsite tracking system(s) to provide visibility and control in three commitment areas:

1. Contractual commitments of deliverables and milestone completions;

2. Administrative/Correspondence/Inquiry/Audit Areas, where a reply is required on specific responses required; and

3. Action item follow-up at the program/project level, to ensure assignments are completed in a timely fashion. 


\subsection{REFERENCES}

DOE-RL, 1995, Single-She 17 Tank Closure Work Plan, DOE-RL-89-16, U.S. Department of Energy, Richland Operations Office, Richland, Washington.

RHO, 1980, Isolation of Auxiliary Tank Farm Facilities, Rockwell Hanford Operations, RHO-CD-977, Rockwe11 Hanford Operations, Richland, Washington.

WHC, 1986. Single-She7l Tank Isolation Safety Analysis Report, WHC-SD-WM-SAR006. Rev 1. Westinghouse Hanford Company, Richland, Washington.

WHC, 1991, Summary of Radioactive Underground Tanks Managed by Hanford Restoration Operations, WHC-SD-DD-TI-057, Rev 0, Westinghouse Hanford Company, Richland, Washington.

WHC. 1993, Hanford Site Tank Farm Facilities Interim Safety Basis. WHC-SD-WMISB-001, Rev 0, Westinghouse Hanford Company, Richland, Washington.

WHC. 1994, Engineering Study of Fifty Miscellaneous Inactive Underground Radioactive Waste tanks Located at the Hanford Site, Washington. WHC-SDEN-ES-040, Rev 4, Westinghouse Hanford Company. Richland, Washington.

WHC, 1994, Guidelines for Declaring Alxiliary Tanks Interim Stabilized, WHCSD-WM-TI-129, Rev 0. Westinghouse Hanford Company, Richland, Washington.

WHC. 1994. Safety Issue Resolution Strategy Plan for Inactive Miscellaneous Underground Storage Tanks, WHC-EP-0775, Westinghouse Hanford Company, Richland, Washington.

WHC, 1994, Single-Shell Tank and Double-Shell Tank Accelerated Safety Analysis: Hazard Identification and Analysis, WHC-SD-WM-PHA-010. Rev 0. Westinghouse Hanford Company, Richland, Washington.

WHC, 1994, Tank Waste Remediation System Administration Manual, Westinghouse, WHC-IP-0842, Rev 3. Westinghouse Hanford Company, Richland, Washington.

WHC, 1995, Operating Specification for Watch-List Tanks, WHC, OSD-T-151-00030. Westinghouse Hanford Company. Richland, Washington.

WHC, 1995, Preliminary Hazards Analysis of the Miscellaneous Underground Storage Tanks, WHC-SD-WM-PHA-001, Rev 0. Westinghouse Hanford Company, Richland, Washington. 
WHC-SD-WM-PD-046, Rev 0

Appendix A

TANK LOCATIONS

\section{INACTIVE MISCELLANEOUS UNDERGROUND STORAGE TANKS}




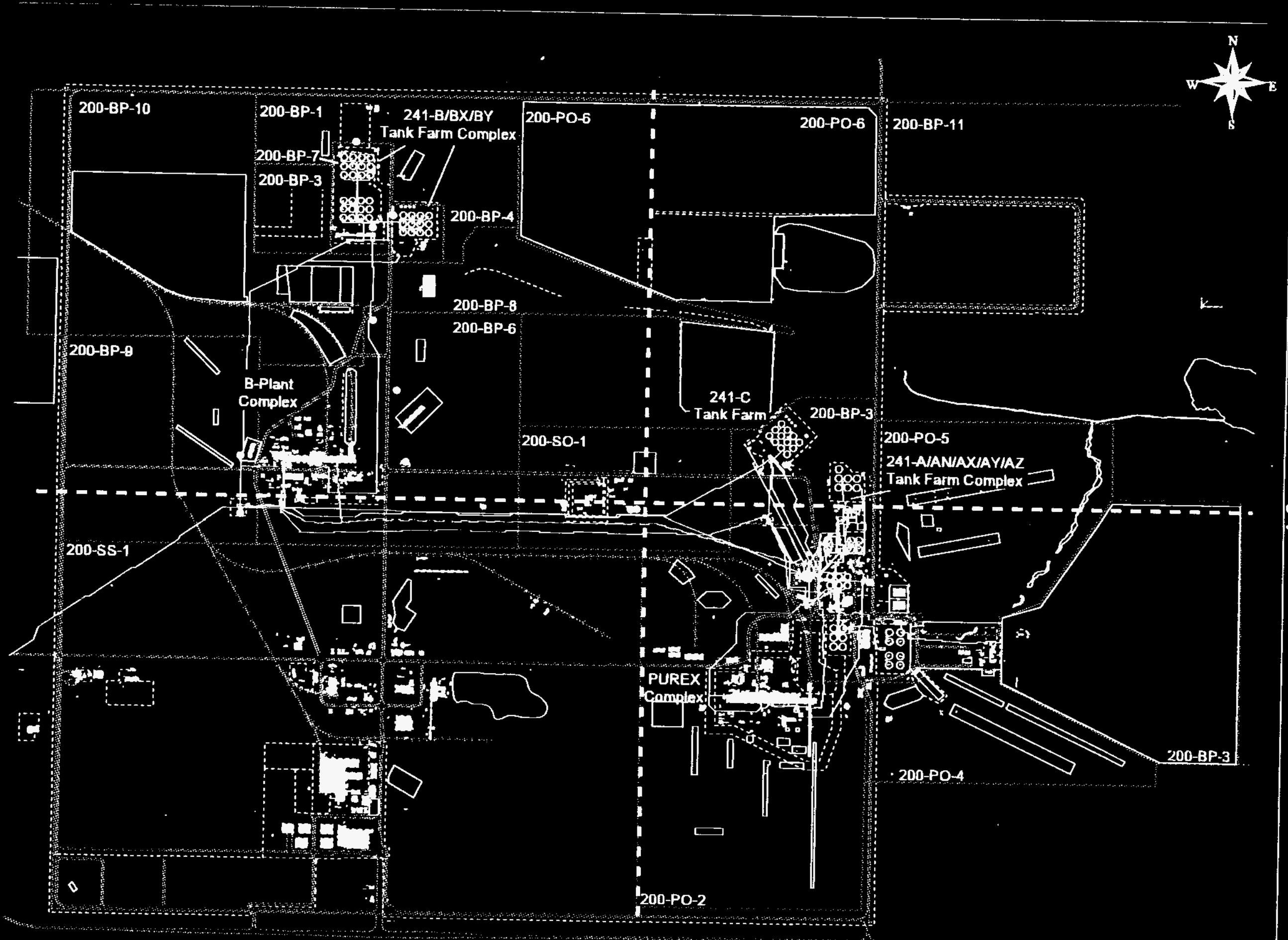




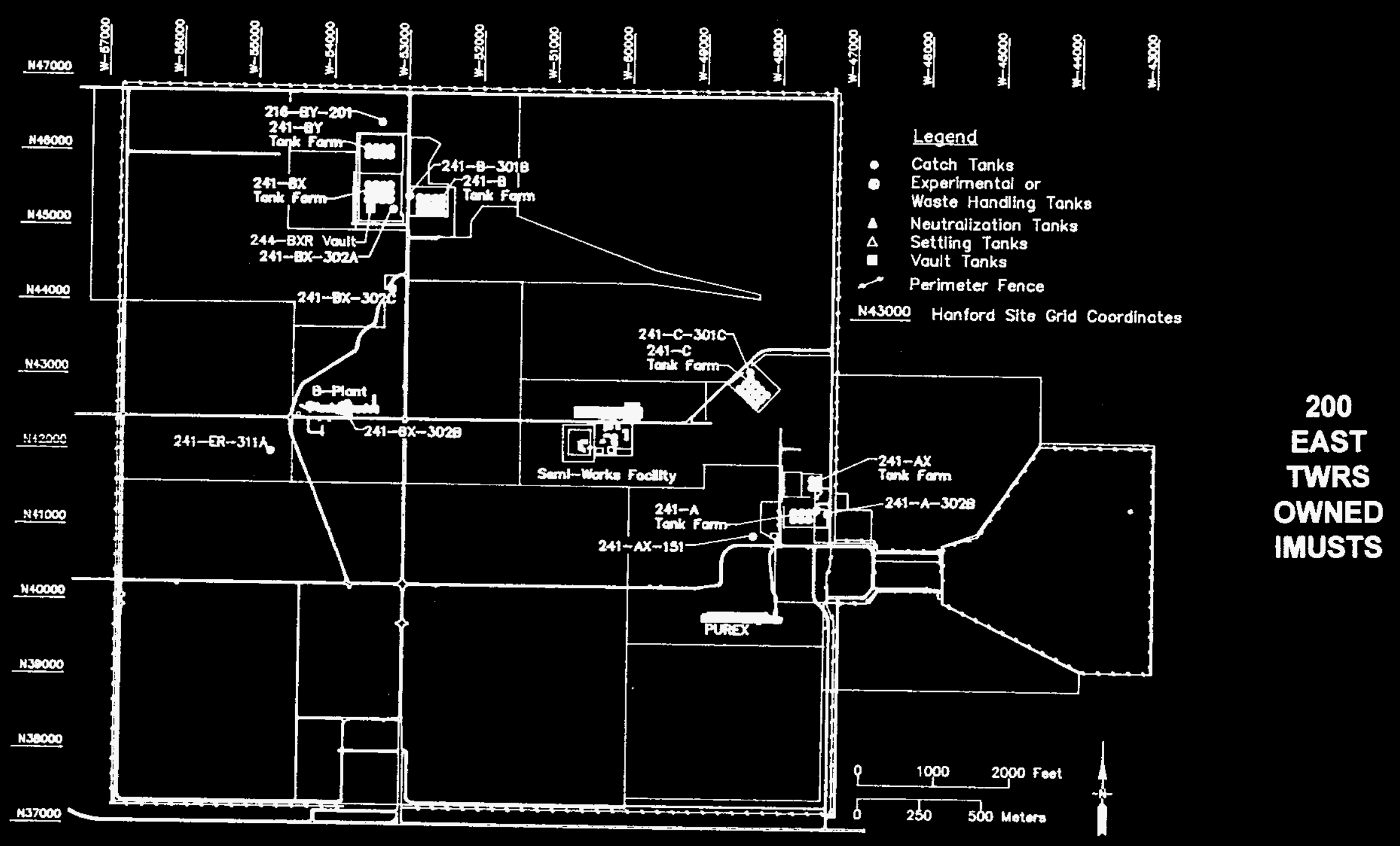

SFP $\backslash 101293-A$ 
$v v-0-2=-v y--2-0<,-\theta v$









$V v-c-5-W V=2-465$, 7ev 


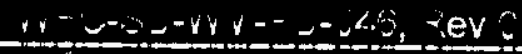

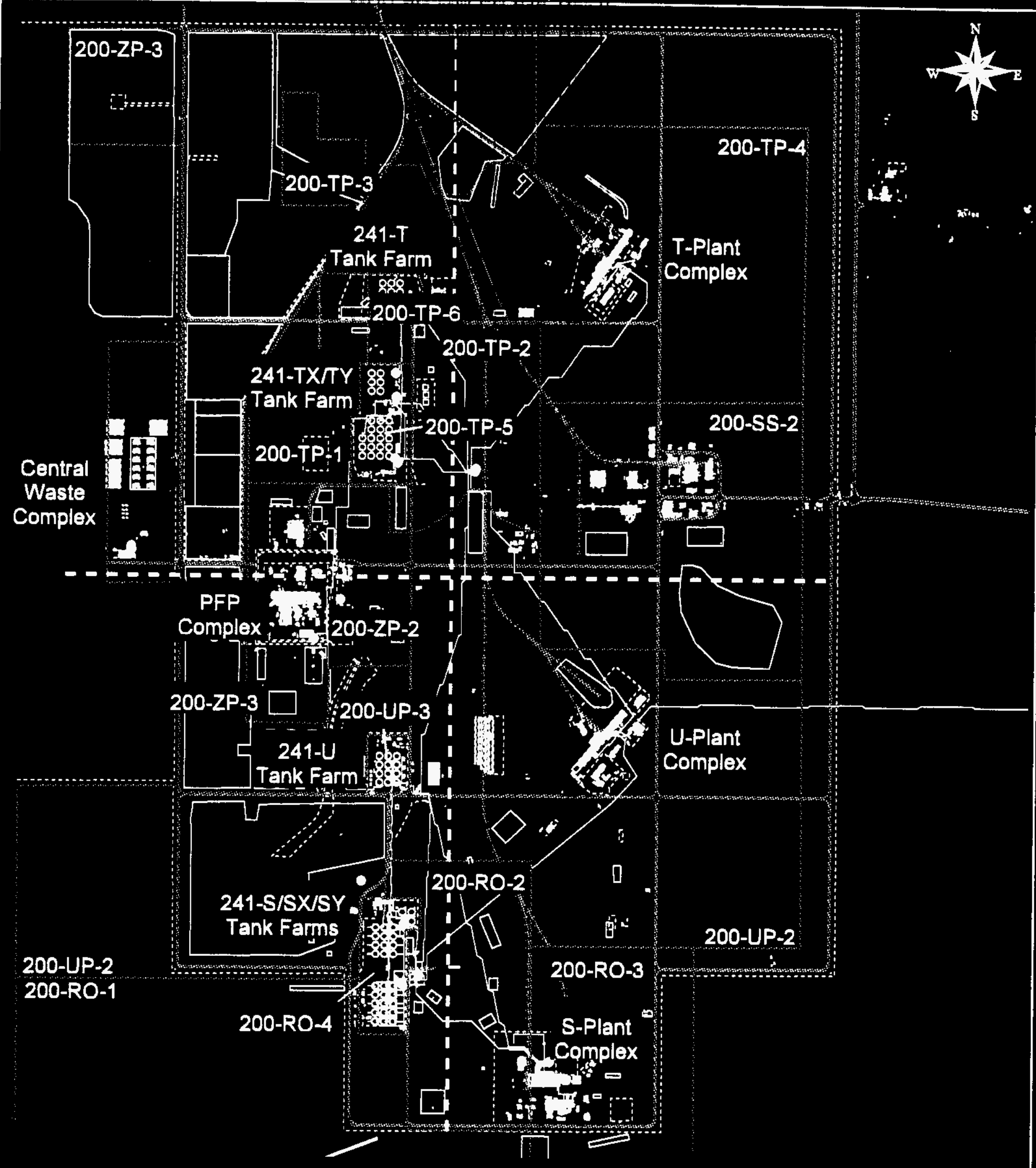




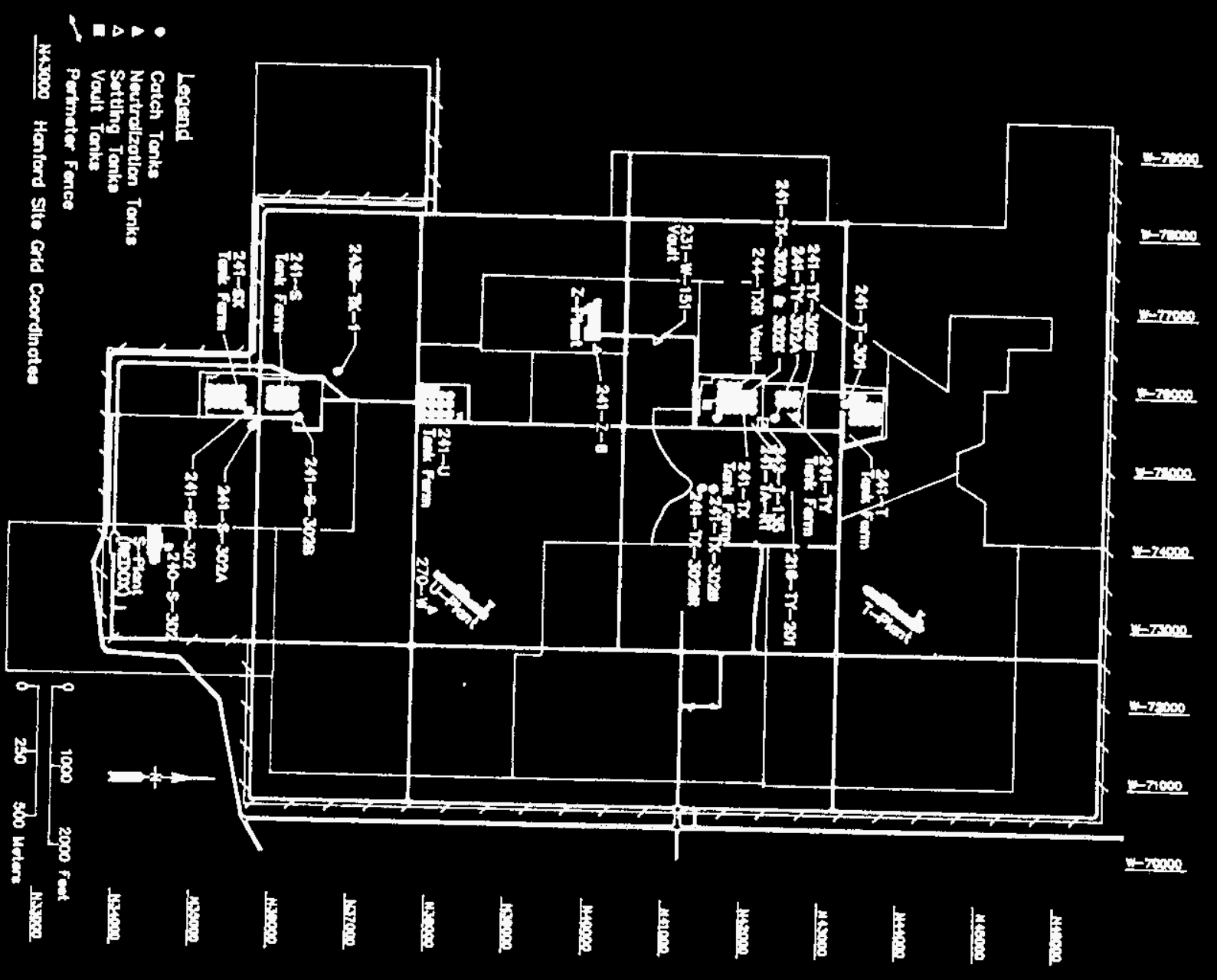

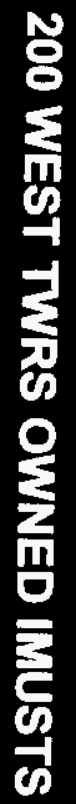


VV-C-S_-WVV-OJ-OKL, Fev

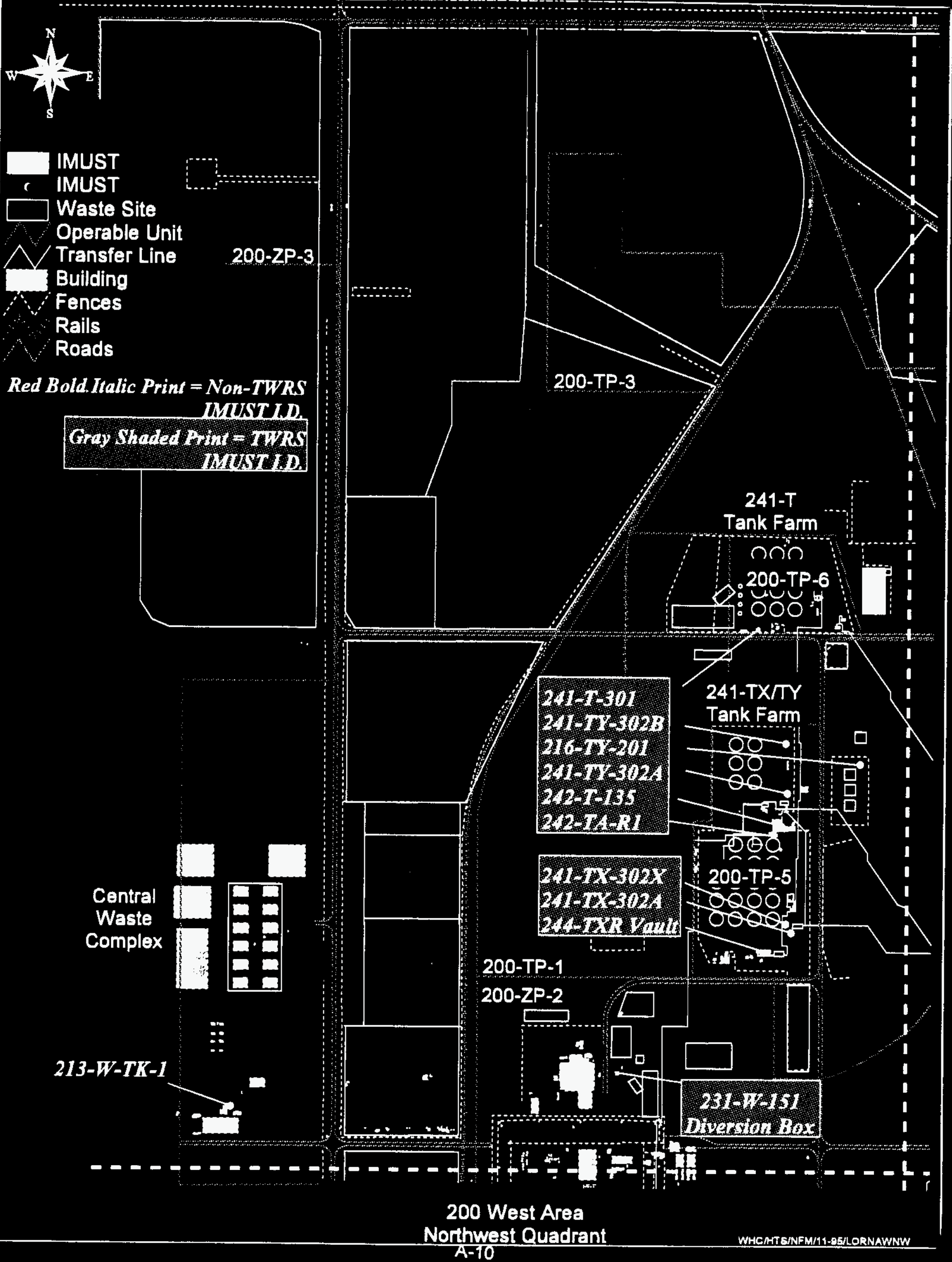







W'-1C-SD-WM-PD-046, Rev 0

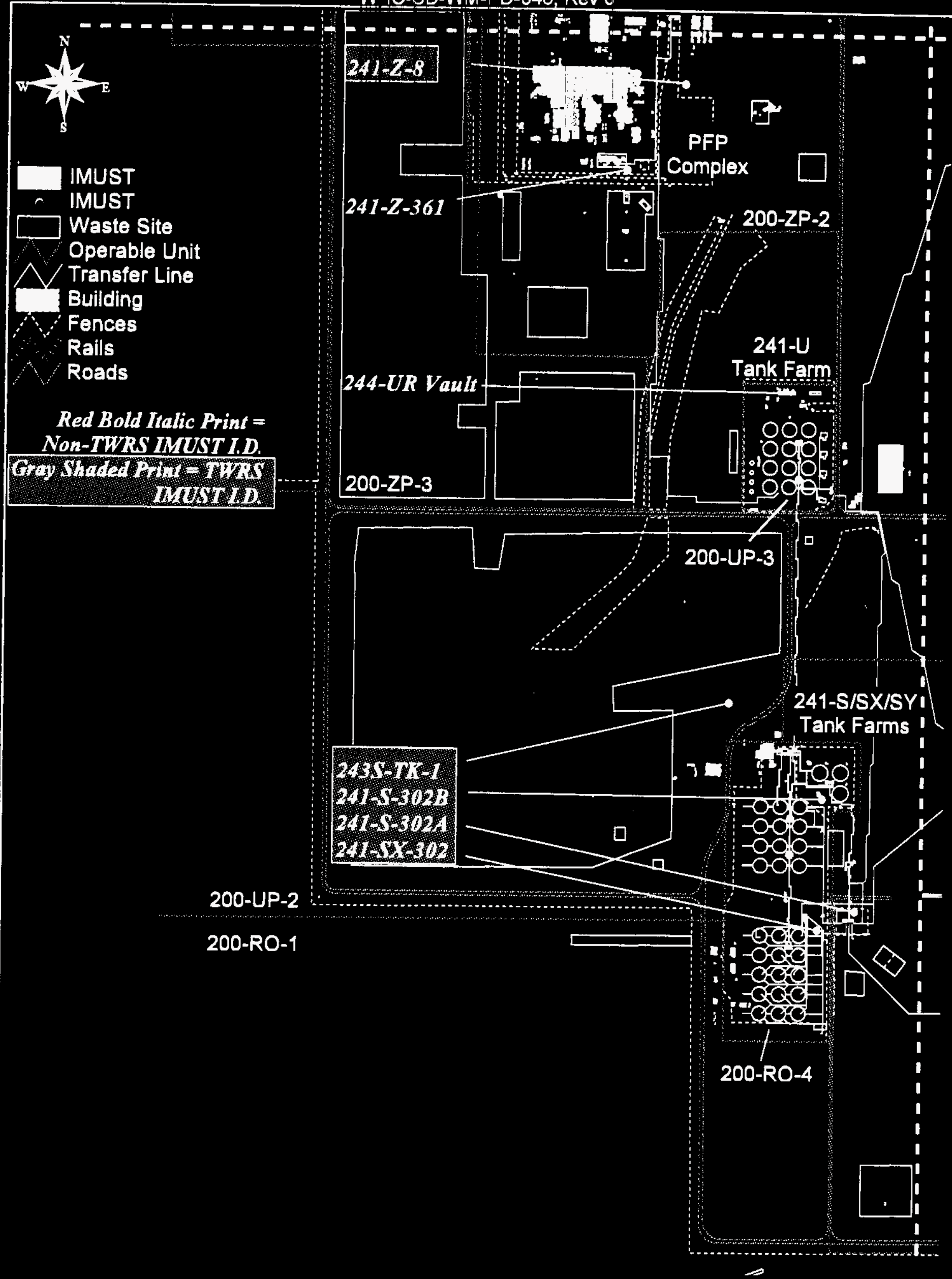


Appendix B

\section{PROGRAM STRATEGY AND HISTORICAL BASIS FOR INACTIVE MISCELLANEOUS UNDERGROUND STORAGE TANKS}


WHC-SD-WM-PD-046, Rev 0

\subsection{INTRODUCTION}

The technical strategy has been developed to accommodate the multiplicity of requirements and constraints imposed on the program; one of the more significant of these is the limitations in currently available engineering data associated with the tanks.

The strategy is designed to achieve a basic and immediate objective for each Inactive Miscellaneous Undergreound Storage Tank (IMUST). The objective is to achieve an equivalence of the Single-Shel1 Tank (SST) Controlled, Clean, and Stable (CCS) end-state for the IMUSTs. This end-state condition wi 77 be one defined for each IMUST, in comparison with the SSTs. It will not generally require that all SST CCS criteria be applicable for each IMUST because the IMUST tanks, being considerably smaller than the SSTS, do not have the same potential for safety issues.

Establishing an equivalent CCS condition for the IMUSTs constitutes closure of the Tank Waste Remediation System (TWRS) IMUST Program, because completing the CCS activities for the IMUSTs in the Single-She11 Tank Farms will allow the Tank Farm Transition Projects (TFTP) to reduce long-term tank survei 1lance and maintenance costs. For the duration that the tanks are in TFTP, this may prove to be the only action necessary for TFTP to take, prior to transferring the tanks to another group for retrieval and closure.

\subsection{IDENTIFICATION OF TWRS-OWNED IMUSTS}

Identifying the tanks within TWRS ownership responsibility is one of the first program tasks. The tank list is subject to change as stakeholder requirements and other issues become resolved. However, early designation of the tank list is important for program management purposes. The knowledge of the number of tanks and which tanks are a part of the program allows for clear definition of the current program scope and aids in program costing forecasts.

Tanks currently identified as TWRS-owned are listed in Table 1-1 of the main text, and those remaining and not identified as TWRS-owned are listed in Table 1-2 of the main text. Maps showing the location of the TWRS IMUSTs are provided in Appendix A. There are a total of 36 tanks on the TWRS-owned list, and 27 on the non-TWRS-owned list.

\subsection{TRANSITION OF TWRS IMUSTS TO THE CCS MODE}

The immediate objective is to transition the IMUSTs associated with particular tank farms into the CCS Program for that tank farm. To achieve this. Engineering Evaluation documents will be prepared for each Tank Farm to summarize findings, based on currently available data.

The TWRS IMUSTS will be evaluated to determine if any additional safety analyses, characterization, tank inspections, stabilization/isolation, or monitoring upgrades are required to meet CCS endpoint criteria. The CCS endpoint criteria that have been recommended for the TWRS IMUSTs only require that:

1) Risks posed by potential safety issues can be demonstrated to be bounded by existing SST Safety Analyses: 
2) Tanks have previous ly been stabilized and isolated in accordance with the criteria specified in WHC-IP-0842; and

3) Tanks with greater than 5,000 gal of liquid remaining be provided with on-7ine monitoring capability (i.e., ENRAFs installed and connected to Tank Monitoring and Control Systems (TMACS).

The CCS requirements would only be applied to IMUSTs physically located within the tank farm perimeters.

Regarding the first criteria, some limited characterization may be required to validate assumptions made for waste composition in the Preliminary Hazards Analysis (WHC 1995b) completed in July 1995.

The second criteria has been met for most, if not a11, of the TWRS IMUSTs. Some additional research of various 200 Area Tank Stabilization/Isolation Projects (Projects B-231, B-138, B-145, B-181, and B-208) wil1 be required to determine which tanks were stabilized and isolated.

The third criteria is not applicable to any of the TWRS-owned IMUSTs. The most recent information indicates that no TWRS-owned tanks within the SingleShe11 Tank Farm perimeters contain more than 5.000 gal remaining in them. However. one tank does not have any documented level reading in the isolation project records. This tank. 241-TA-R1 (located in the 241-TX Tank Farm), may have to be accessed to obtain a level reading to verify compliance with CCS leakage monitoring criteria.

The IMUSTs not associated with a particular tank farm, which cannot be incorporated into the tank farm CCS Program, wi11 be treated comparably to the IMUSTs within tank farm boundaries. This will include any additional safety analyses, characterization, tank inspections, stabilization/isolation, or modifications necessary to meet an acceptable endpoint criterion.

\subsection{Previous Stabilization Activities}

Most IMUSTs were interim-stabilized and interim-isolated before September 1985, with the majority being isolated in Project B-231 (WHC 1986). This project interim-stabilized and interim-isolated numerous catch tanks, vaults, diversion boxes, diverter stations, valve pits, and pipeline encasements to prevent inadvertent liquid additions to these facilities and to protect the environment from possible releases of radioactive materials (RHO 1980). Wastes in these inactive facilities were first interim-stabilized by removing liquid to reduce the mobility of radiological contaminants, and the wastes and facility were then interim-isolated for safe storage until final disposal (WHC 1986).

Individual tank evaluations were performed during Project B-231 to determine whether and when a tank was to be considered interim-stabilized. These tank evaluations, and their current tank or sump liquid and solid level

measurements at that time, were documented and approved on a Stabilization Evaluation Form, which then became part of the project records (WHC 1994a). Because measurements were typically obtained just prior to tank isolation. they are the best available data concerning current tank waste volumes. 
WHC-SD-WM-PD-046, Rev 0

Current estimates of the actual waste volumes remaining in the tanks are questionable because of measurement and volume discrepancies in the historical records. Thus, for selected IMUSTs, it may prove necessary to verify level measurements.

\subsection{Tank Modifications}

When the IMUSTs were interim isolated, most had the liquid-level measuring devices removed, and blind flanges were installed on the above-ground tank risers. Only five of the initial 50 IMUSTs are currently monitored for leakage or intrusion. The tanks being monitored are Tanks 241-B-302B. 241-ER-311A, 240-S-302, 241-S-302A, and 241-TX-302B.

Some tanks that pose a significant risk for leakage are not presently monitored. Tanks thought to contain a significant quantity of liquids (more than 5.000-gal supernate) may require installation of continuous online remote leak detection instrumentation. The basis for the 5,000-gal supernate limits in leak detection criteria is that those are the levels at which IMUSTs were considered to be interim-stabilized when they were isolated in the mid-1980s. The interim stabilization criteria are discussed in the Engineering Study of Fifty Miscellaneous Inactive Underground Radioactive Waste Tanks Located at the Hanford Site. Washington. Section 2.3 (WHC 1994a).

\subsection{CHARACTERIZATION}

The demand for tank farm space historically has been high at the Hanford Site. To accommodate operation of a new process, or relocation of a particular waste type for ease of operation, waste was often transferred from one tank to another, sometimes within a tank farm and sometimes between tank farms. The high number of these tank farm transfers and their diversity make estimating waste composition a very difficult process. The miscellaneous tanks most affected by the inter-tank transfers were the catch tanks. These tanks were connected to drains from diversion boxes that could be reconfigured to align waste transfers to and from a variety of sources. This makes correlation of SST wastes to miscellaneous tanks questionable because research indicates that full knowledge of all waste transfer routings, and particularly associated quantitative information on waste spillage and leakage. is not available. Thus, reliable quantitative information on miscellaneous tank waste content. especially catch tanks, may not be derived through process knowledge alone.

The overall IMUST characterization strategy is to obtain as much of the current information as possible, within program constraints. The amount of information required is to be developed based on a set of necessary and sufficient conditions for an equivalent CCS endstate. These conditions act to bound in a semi-quantifiable way those items that are most significant for CCS. For future cases in which tank content samples have been obtained and analyzed and tank integrity has been field determined, more quantified Engineering Evaluations could be prepared based on the new data.

Priorities have previously been established for characterization of the IMUSTs in the Safety Issue Resolution Strategy Plan for Inactive Miscellaneous Underground Storage Tanks (WHC 1994C). Table 2 of the Preliminary Hazards Analysis (PHA) provides this priority listing. These priorities were developed using preliminary information on the risks for potential safety 
issues in the IMUSTS. The risks, which were qualitatively evaluated, were considered with the Data Quality Objectives used in the Double-Shell Tank (DST) and SST Safety Program. This priority list had, as its underlying objective, the complete characterization of the waste contents and resolution of all potential safety issues for the IMUSTs (WHC 1994C. Figure 2-1). The new TWRS IMUST Program objective is limited to developing a bounding safety basis that will greatly reduce the characterization effort scope because only selected tanks will be further characterized.

In a graded approach, the strategy proposed for improving characterization of the IMUSTs would require sampling of a conservatively chosen group of tanks thought to be representative of each of the potential safety issues cited in the PHA. For example, under this strategy, only selected tanks from the set of all potential hydrogen IMUSTs would be sampled. Table B-1 provides the tank categories based on the potential safety issue listings in the PHA. Tanks chosen for sampling would be those representative for each category, based on existing knowledge and conservative assumptions. If only one tank is selected from each category, then only eight samples would be required, rather than 36 if all of the tanks were characterized.

Table B-1. Tank Categories for the Inactive Miscellaneous Underground Storage Tanks.

\begin{tabular}{|c|c|}
\hline Tank Category* & Tank Number \\
\hline Hydrogen & 244-BXR-001,244-BXR-003, and 244-BXR-011 \\
\hline Ferrocyanide & $241-\mathrm{TY}-302 \mathrm{~A}$ \\
\hline Organic &  \\
\hline High Heat &  \\
\hline Criticality & $\begin{array}{l}\text { None with High or Moderate Relative Ranking, all the Tanks Are Low } \\
\text { Ranking. }\end{array}$ \\
\hline Flammable Gas & 244-BXR-001, 244-BXR-003, and 244-BXR-011 \\
\hline Toxic Vapors & $\begin{array}{l}241-\mathrm{A}-302 \mathrm{~B}, 241-\mathrm{B}-301 \mathrm{~B}, 241-\mathrm{B}-302 \mathrm{~B}, 241-\mathrm{BX}-302 \mathrm{~B}, 241-\mathrm{BX}-302 \mathrm{C}, 244-\mathrm{BXR}- \\
001,244-\mathrm{BX}-002,244-\mathrm{B} X \mathrm{R}-003,244-\mathrm{BXR}-011,241-\mathrm{C}-301 \mathrm{C}, 240-\mathrm{S}-302,241- \\
\mathrm{S}-302 \mathrm{~A}, 241-\mathrm{SX}-302,241-\mathrm{T}-301,241-T X-302 \mathrm{~A}, 241-\mathrm{TX}-302 \mathrm{~B}, 241-\mathrm{TX}-302 \mathrm{X}, \\
241-\mathrm{TY}-302 \mathrm{~A}\end{array}$ \\
\hline High Radiation & 242-TA-R1 \\
\hline
\end{tabular}

\subsection{REGULATORY COMPLIANCE}

The program Regulatory Compliance Plan will provide the framework for a compliance strategy that will be used for the IMUSTs until final closure. The strategy will form the basis for future actions that may be required to achieve final closure. Additionally, this plan will include the compliance 
strategy for other regulatory compliance requirements not specifically identified in the RCRA statutes (i.e., CERCLA and NESHAPS).

The compliance strategy will be based on precedents established for the SSTs. It is logical to apply the same or similar compliance requirements because the TWRS IMUSTs were used for waste collection, transport, and storage operations in much the same way as the SSTS were used, and because the waste constituents, tank design, and mechanisms for environmental impact and offsite releases for the IMUSTS are similar or identical to the SSTS.

Waste transfers to the SSTS were discontinued in 1980. Although pumping operations have been ongoing as part of the SST Stabilization Program, there have been no routine waste transfers since 1980. Because none of the SSTs have been operational subsequent to enactment of the RCRA statute. they are considered "Past Practice Units" and required to be maintained in compliance with Interim Status requirements, rather than a RCRA permit. The general requirements and schedule for future waste retrieval/remediation and final closure activities are specified in the Hanford Site Federal Facilities Agreement and Consent Order or Tri-Party Agreement (TPA).

The IMUSTs are not believed to be subject to the same Interim Status requirements that are applied to the SSTs. Additionaliy, no TPA mi lestones have been established to govern future waste management activities for the IMUSTS. The IMUST Regulatory Compliance Plan will serve as the framework for negotiating future compliance agreements and/or TPA milestones. If and when such agreements have been established, the Compliance Plan wi 11 be updated to specify how these requirements will be applied and how compliance will be monitored.

\subsection{REFERENCES}

DOE-RL, 1995, Single-She 71 Tank Closure Work Plan, DOE-RL-89-16, U.S. Department of Energy, Richland Operations Office, Richland, Washington.

RHO, 1980, Isolation of Auxiliary Tank Farm Facilities, Rockwell Hanford Operations, RHO-CD-977, Rockwe11 Hanford Operations, Richland, Washington.

WHC, 1986. Single-She 71 Tank Isolation Safety Analysis Report. WHC-SD-WM-SAR006. Rev 1. Westinghouse Hanford Company, Richland, Washington.

WHC. 1991, Summary of Radioactive Underground Tanks Managed by Hanford Restoration Operations, WHC-SD-DD-TI-057, Rev 0, Westinghouse Hanford Company. Richland. Washington.

WHC, 1993. Hanford Site Tank Farm Facilities Interim Safety Basis, WHC-SD-WMISB-001, Rev 0, Westinghouse Hanford Company. Richland. Washington.

WHC. 1994a. Engineering Study of Fifty Miscellaneous Inactive Underground Radioactive Waste tanks Located at the Hanford Site, Washington. WHC-SDEN-ES-040, Rev 4, Westinghouse Hanford Company, Richland, Washington.

WHC, 1994b, Guidelines for Declaring Auxiliary Tanks Interim Stabilized, WHCSD-WM-TI-129, Rev 0. Westinghouse Hanford Company, Richland, Washington. 
WHC. 1994c, Safety Issue Resolution Strategy Plan for Inactive Miscellaneous Underground Storage Tanks. WHC-EP-0775, Westinghouse Hanford Company. Richland, Washington.

WHC, 1994d, Single-Shel1 Tank and Double-She 71 Tank Accelerated Safety Analys is: Hazard Identification and Analys is, WHC-SD-WM-PHA-010, Rev 0. Westinghouse Hanford Company, Richland, Washington.

WHC, 1994e, Tank Waste Remediation System Administration Manua7, Westinghouse. WHC-IP-0842. Rev 3, Westinghouse Hanford Company. Richland, Washington.

WHC, 1995a, Operating Specification for Watch-List Tanks, WHC, OSD-T-15100030. Westinghouse Hanford Company. Richland, Washington.

WHC, 1995b. Preliminary Hazards Analysis of the Miscellaneous Underground Storage Tanks, WHC-SD-WM-PHA-001, Rev 0. Westinghouse Hanford Company. Richland, Washington. 
WHC-SD-WM-PD-046, Rev 0

\section{Appendix C}

\section{PLANNING MATRICES}

INACTIVE MISCELLANEOUS UNDERGROUND STORAGE TANKS 
WHC-SD-WM-PD-046, Rev 0

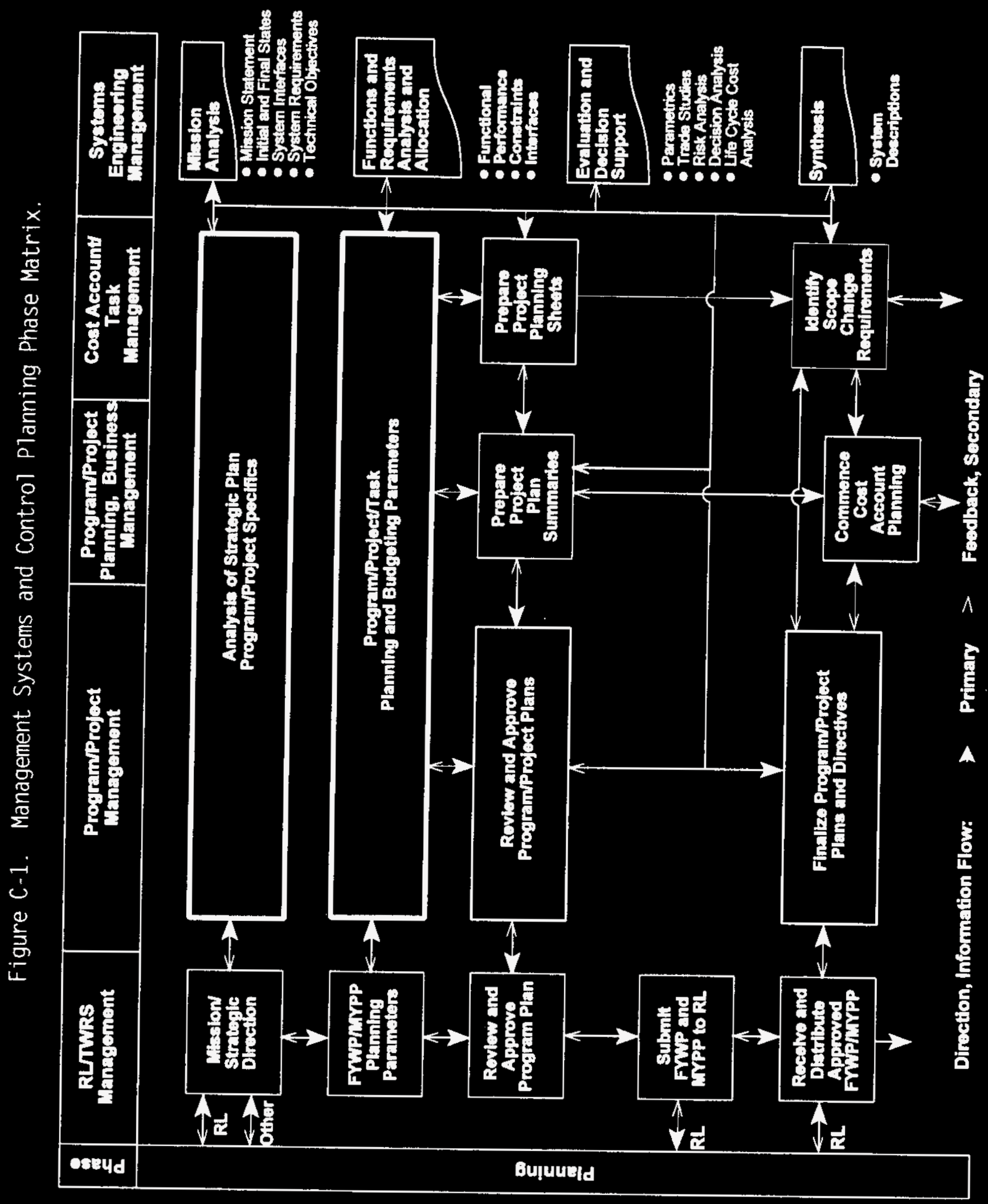


Figure C-2. Work Authorization and Control Phase.

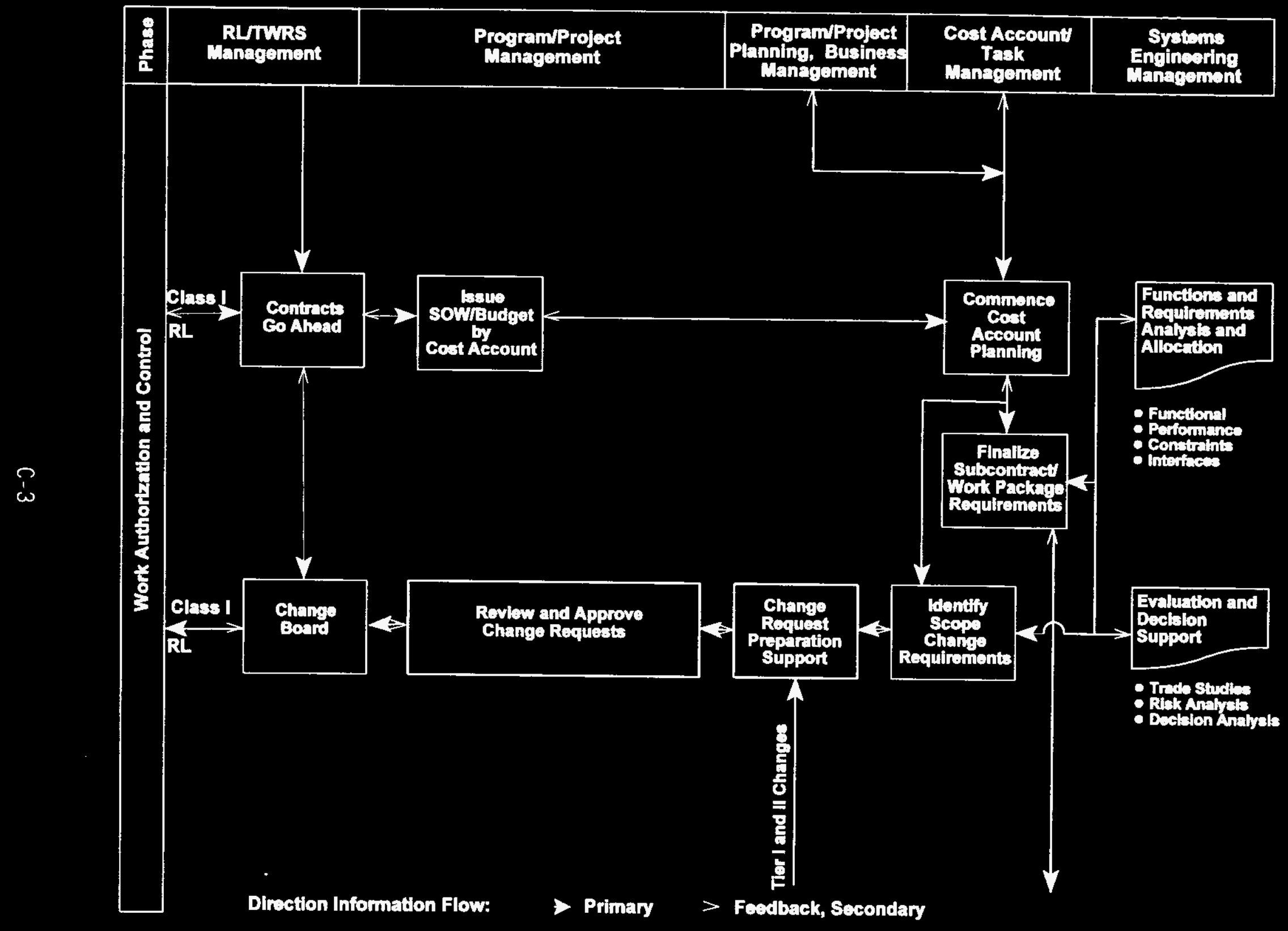









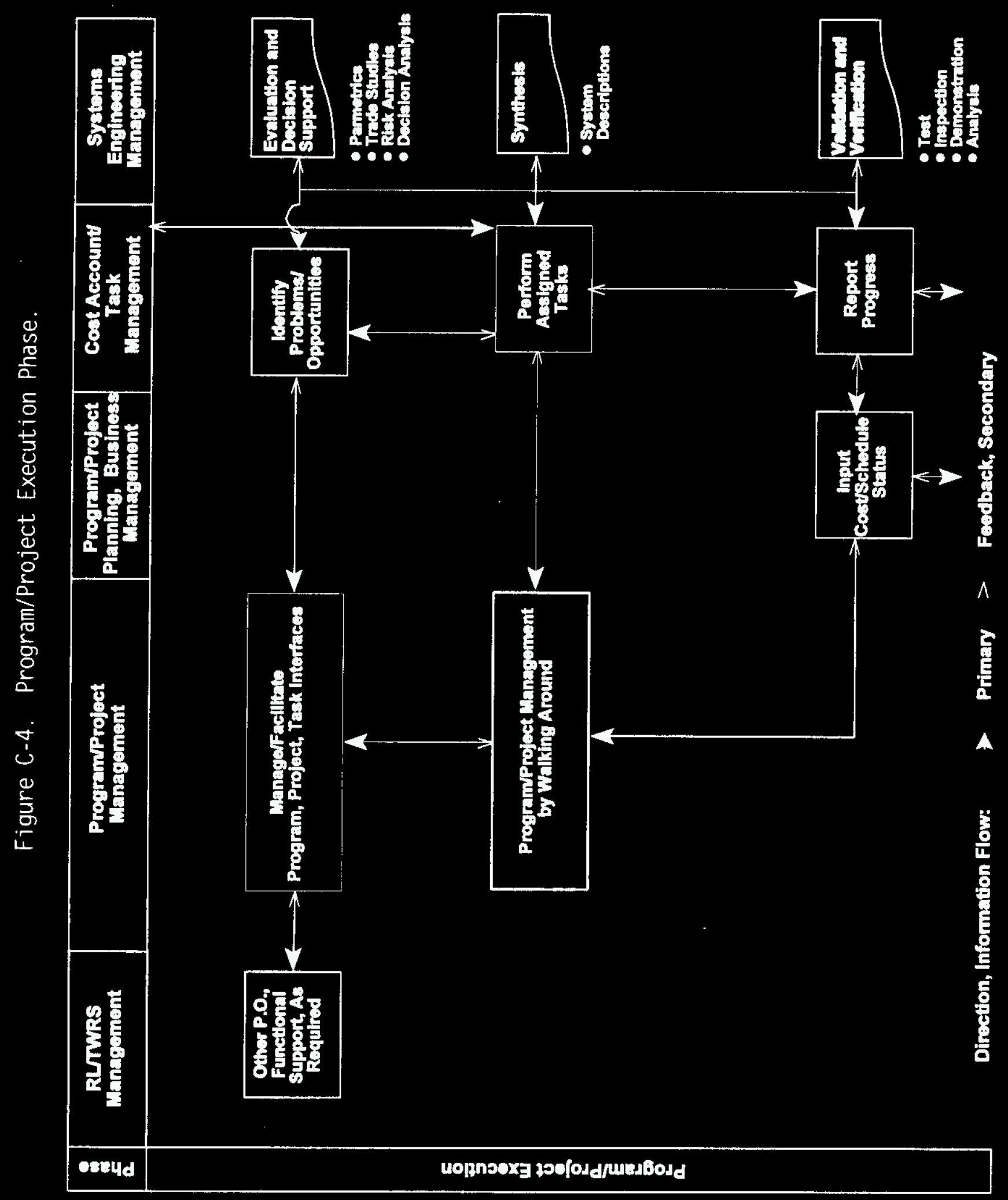


Figure C-5. Performance Analysis and Reporting Phase.

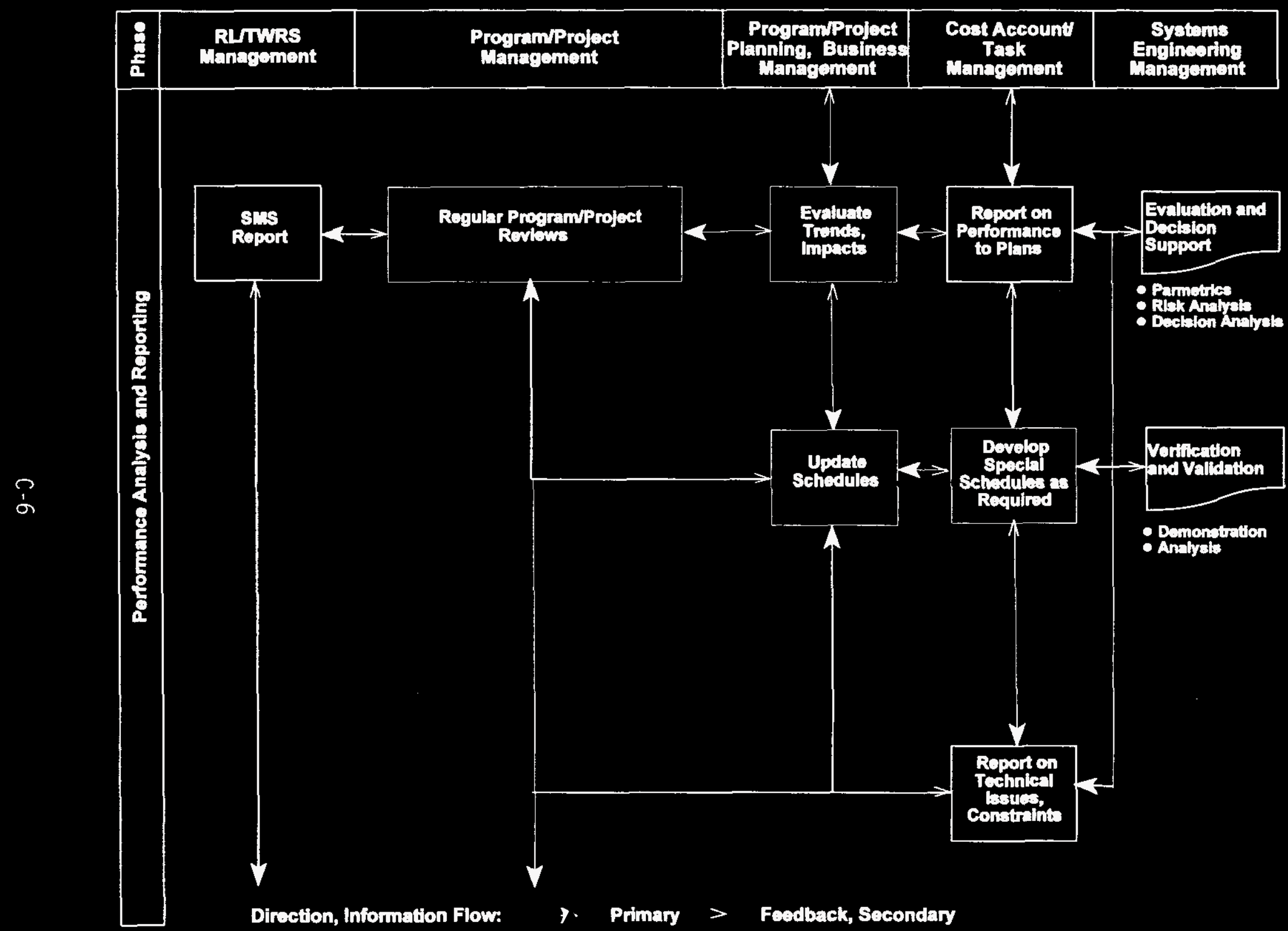


WHC-SD-WM-PD-046, Rev 0

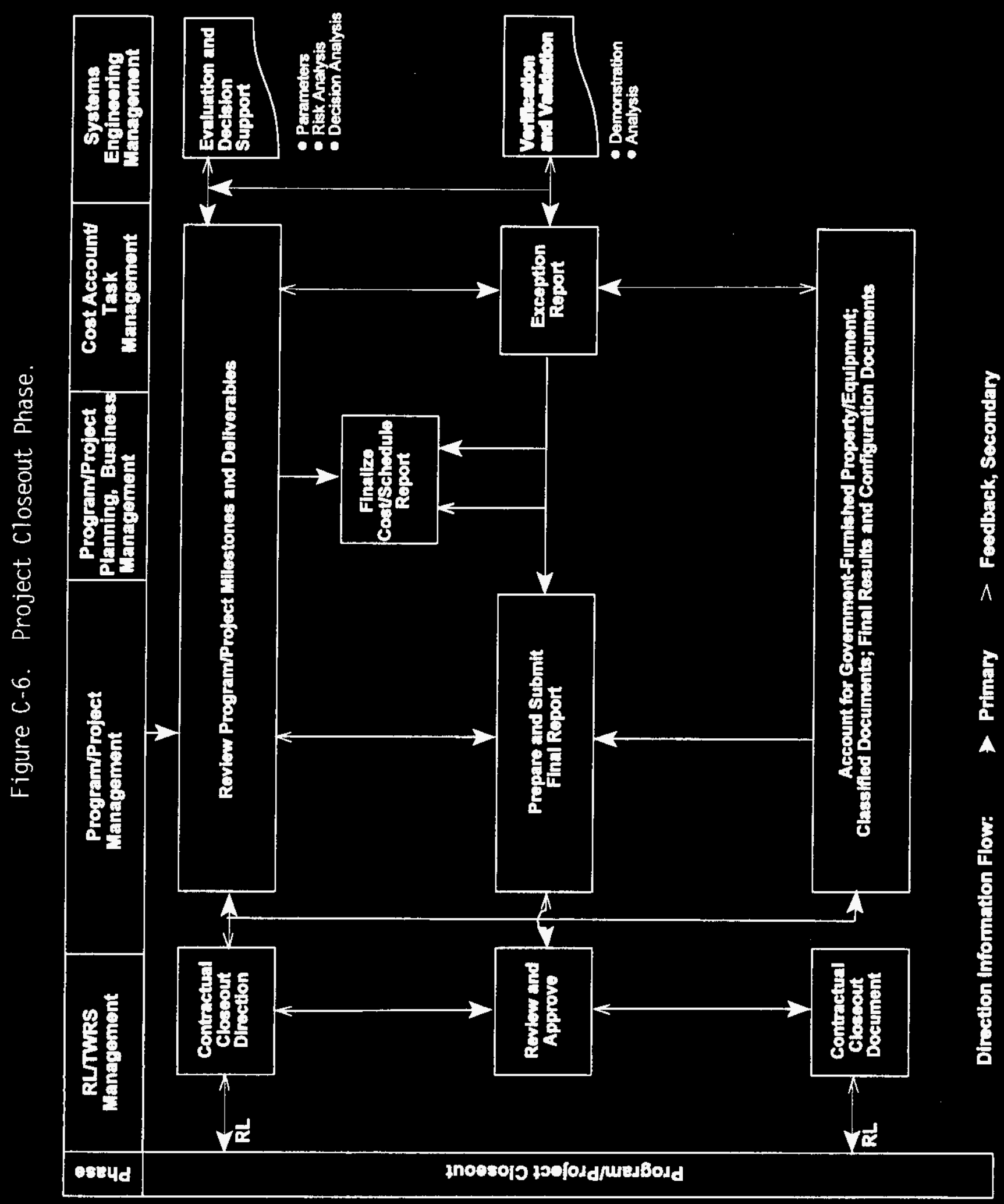


WHC-SD-WM-PD-046, Rev 0

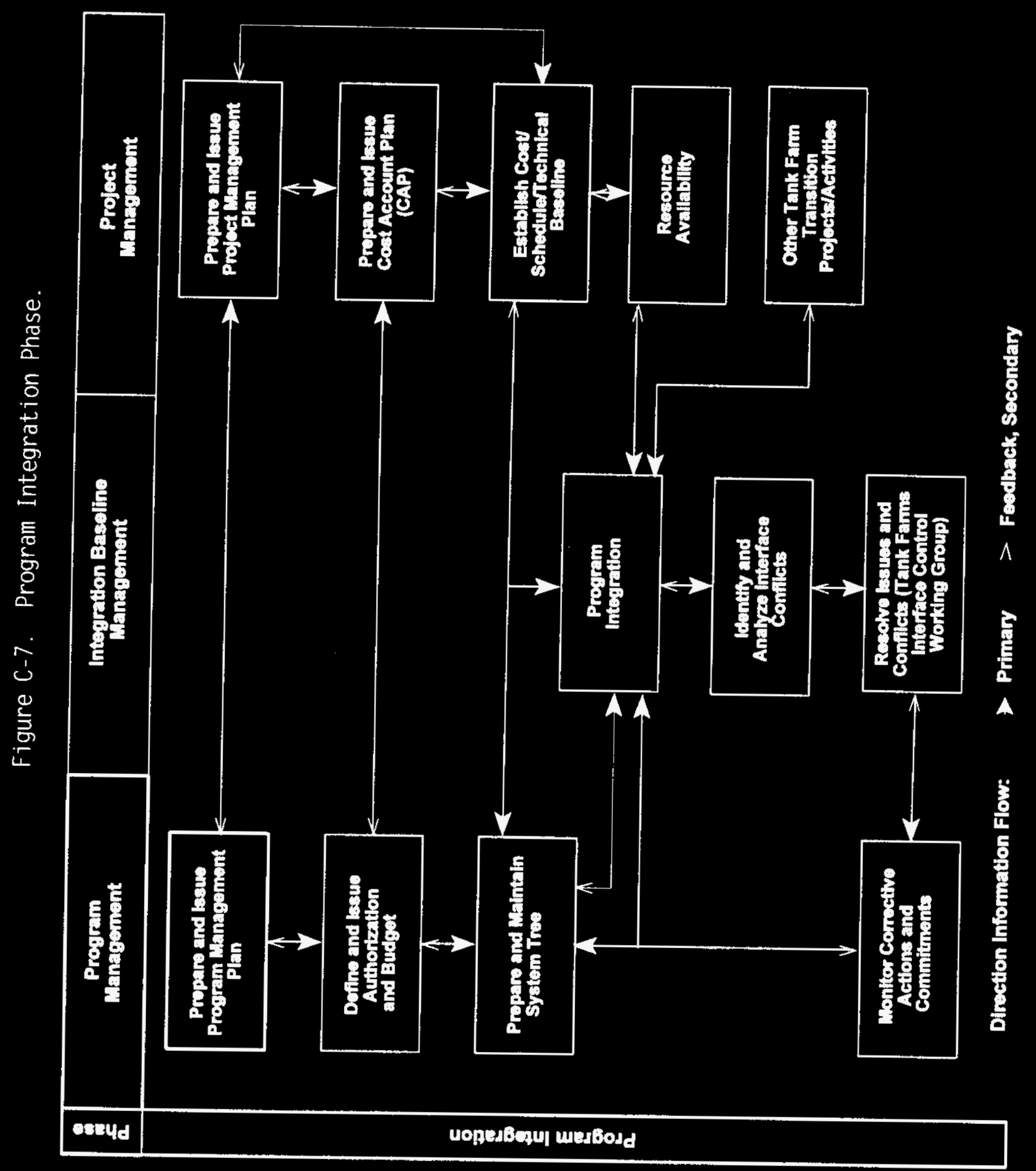




\section{DISTRIBUTION SHEET}

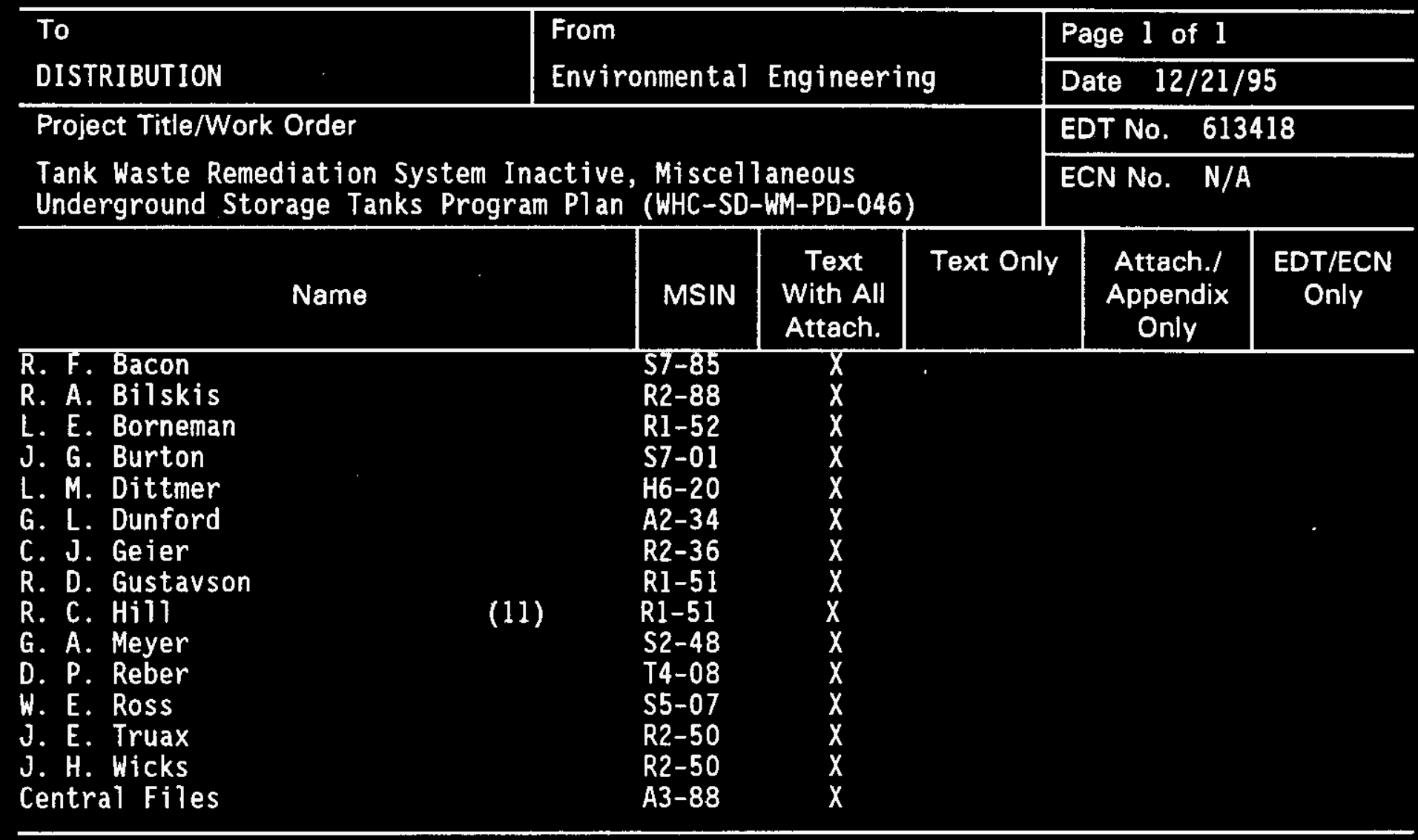

